\title{
Rare fungal infectious agents: a lurking enemy [version 1;
}

\section{peer review: 4 approved]}

\author{
Anna Skiada (1D1, Ioannis Pavleas², Maria Drogari-Apiranthitou ${ }^{3}$ \\ 11st Department of Medicine, Laiko Hospital, School of Medicine, National and Kapodistrian University of Athens, Athens, Greece \\ 2Intensive Care Unit, Laiko Hospital, Athens, Greece \\ ${ }^{3}$ Infectious Diseases Research Laboratory, 4th Department of Internal Medicine, School of Medicine, National and Kapodistrian \\ University of Athens, Athens, Greece
}

V1 First published: 31 Oct 2017, 6(F1000 Faculty Rev):1917

https://doi.org/10.12688/f1000research.11124.1

Latest published: 31 Oct 2017, 6(F1000 Faculty Rev):1917

https://doi.org/10.12688/f1000research.11124.1

\begin{abstract}
In the expanding population of immunocompromised patients and those treated in intensive care units, rare fungal infectious agents have emerged as important pathogens, causing invasive infections associated with high morbidity and mortality. These infections may present either as de novo or as breakthrough invasive infections in high-risk patients with hematologic malignancies receiving prophylactic or empirical antifungal therapy or in patients with central venous catheters. Diagnosis and treatment are challenging. Physicians should have a high index of suspicion because early diagnosis is of paramount importance. Conventional diagnostic methods such as cultures and histopathology are still essential, but rapid and more specific molecular techniques for both detection and identification of the infecting pathogens are being developed and hopefully will lead to early targeted treatment. The management of invasive fungal infections is multimodal. Reversal of risk factors, if feasible, should be attempted. Surgical debridement is recommended in localized mold infections. The efficacy of various antifungal drugs is not uniform. Amphotericin B is active against most yeasts, except Trichosporon, as well as against Mucorales, Fusarium, and some species of Paecilomyces and dimorphic fungi. The use of voriconazole is suggested for the treatment of trichosporonosis and scedosporiosis. Combination treatment, though recommended as salvage therapy in some infections, is controversial in most cases. Despite the use of available antifungals, mortality remains high. The optimization of molecular-based techniques, with expansion of reference libraries and the possibility for direct detection of resistance mechanisms, is awaited with great interest in the near future. Further research is necessary, however, in order to find the best ways to confront and destroy these lurking enemies.
\end{abstract}

Keywords

invasive fungal infections, rare, yeast, mold, mucormycosis , trichosporon

\section{Open Peer Review}

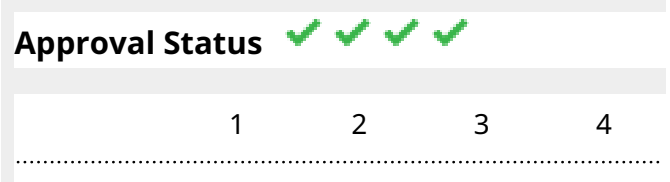

version 1

31 Oct 2017

Faculty Reviews are review articles written by the prestigious Members of Faculty Opinions. The articles are commissioned and peer reviewed before publication to ensure that the final, published version is comprehensive and accessible. The reviewers who approved the final version are listed with their names and affiliations.

1. Jacques Meis, Canisius-Wilhelmina Hospital(CWZ), and Centre of Expertise in Mycology Radboudumc/CWZ, Nijmegen, The Netherlands

2. Jean-Phillipe Bouchara, Université d'Angers, Angers, France

Centre Hospitalier Universitaire d"Angers, Angers, France

3. Tania C Sorrell, University of Sydney at Westmead Hospital, Westmead, Australia University of Sydney, Westmead, Australia 
4. Flavio Queiroz-Telles, Federal University of Paraná, Curitiba, Brazil

Any comments on the article can be found at the end of the article.

Corresponding author: Anna Skiada (askiada@otenet.gr)

Competing interests: The authors declare that they have no competing interests.

Grant information: The author(s) declared that no grants were involved in supporting this work.

Copyright: @ 2017 Skiada A et al. This is an open access article distributed under the terms of the Creative Commons Attribution License, which permits unrestricted use, distribution, and reproduction in any medium, provided the original work is properly cited.

How to cite this article: Skiada A, Pavleas I and Drogari-Apiranthitou M. Rare fungal infectious agents: a lurking enemy [version 1; peer review: 4 approved] F1000Research 2017, 6(F1000 Faculty Rev):1917 https://doi.org/10.12688/f1000research.11124.1

First published: 31 Oct 2017, 6(F1000 Faculty Rev):1917 https://doi.org/10.12688/f1000research.11124.1 


\section{Introduction}

The quest for the early diagnosis and effective treatment of invasive fungal infections is ongoing, and there are still many obstacles to overcome. The main agents responsible for these infections are members of the genera Candida, Cryptococcus, and Aspergillus. However, there are other fungi, yeasts, and molds, which, though rare in human disease, can cause equally serious and life-threatening infections in immunocompromised and other susceptible hosts. These include yeasts (Trichosporon, Magnusiomyces, Saprochaete, Rhodotorula, Saccharomyces, and Malassezia), mucormycetes, hyaline molds, dematiaceous (melanized) molds, and some novel taxa of thermally dimorphic fungi. Furthermore, a new Candida species, $C$. auris, has emerged and may pose a threat to hospitalized patients. The aim of this review is to present an update on invasive infections due to these rare and emerging fungi, focusing on new developments in diagnostic methodologies and therapeutic modules. In the light of recent taxonomic research and nomenclature changes of many pathogens, this review, though clinically oriented, will inevitably refer to some of these recent advances.

\section{Rare yeasts}

Infections due to yeasts other than Candida and Cryptococcus account for about 2 to $3 \%$ of all fungemias ${ }^{1-3}$. They mainly occur in patients with hematologic malignancies or the critically ill. A large proportion of these infections represent breakthrough fungemias in patients already receiving an antifungal agent or are associated with central venous catheters (CVCs). Some of these yeasts are colonizers of the skin or the mucosal surfaces, whereas others may be found in the environment or even in food. The clinical presentation is non-specific, the only characteristic being that cutaneous exanthems are more common than in candidemia ${ }^{4}$. Diagnosis is based on blood cultures.

\section{Candida auris}

C. auris is an emerging, multiple-drug-resistant (MDR) yeast causing a broad range of healthcare-associated invasive infections. It was first reported in Japan in 2009 when an isolate was recovered from the external ear canal of an inpatient ${ }^{4}$. The first bloodstream infections were reported two years later from South $\mathrm{Korea}^{5}$; shortly after that, $C$. auris fungemia was documented in India ${ }^{6-8}$, South Africa ${ }^{9}$, and Kuwait ${ }^{10}$. Since then, this difficult-to-treat yeast has been spreading across several countries in Europe, Asia, and the Americas ${ }^{11-15}$. In a recent study from India, $C$. auris accounted for more than $5 \%$ of candidemia in a national survey of intensive care units (ICUs) 7 . Whole genome sequencing (WGS) and epidemiological analyses, performed by Lockhart et al., led to the conclusion that this species has emerged recently, independently, and almost simultaneously on three continents and not as a result of worldwide dissemination of a dominant clone $^{12}$. The earliest case to date was identified in retrospect by DNA sequencing of a Korean bloodstream isolate from $1996^{5}$.

Most cases of fungemia due to $C$. auris have been reported from hospitalized patients. Patients range from neonates to the elderly and have the well-known risk factors for invasive candidiasis. Like other Candida spp., C. auris colonizes the skin and mucosal surfaces (that is, genitourinary, gastrointestinal, and respiratory tract). In addition, environmental sampling of the clinical area surrounding colonized patients demonstrated contamination of the floor around bed sites, radiators, equipment monitors, mattresses, beds, windowsills, chairs, infusion pumps, and countertops ${ }^{16,17}$.

The phylogeny of $C$. auris is similar to that of $C$. haemulonii, which is another species resistant to amphotericin $\mathrm{B}$ and fluconazole 5 . WGS data also revealed a relationship to $C$. lusitaniae, which is intrinsically resistant to many antifungals ${ }^{18,19}$. Commercial identification systems, such as Vitek 2 and API20C-AUX, misidentify this yeast as C. haemulonii, C. famata, C. sake, Saccharomyces cerevisiae, and Rhodotorula glutinis and this misidentification is primarily due to a lack of $C$. auris in the database of these systems ${ }^{5,6,9}$. The most reliable methods for diagnosis of $C$. auris are molecular-based ones, such as amplified fragment length polymorphism (AFLP) fingerprinting and sequencing analysis ${ }^{20,21}$. Matrix-assisted laser desorption/ionization time-of-flight mass spectrometry (MALDI-TOF MS) systems (Bruker and Vitek MALDI-TOF MS) also have the potential for an accurate identification given the incorporation of a library containing $C$. auris and a proper extraction method ${ }^{21}$. In a recently published study, where the isolates from 54 patients were analyzed, 93\% were found to be resistant to fluconazole, $35 \%$ to amphotericin $\mathrm{B}$, and $7 \%$ to echinocandins, while $41 \%$ were resistant to two antifungal classes and $4 \%$ were resistant to three classes ${ }^{12}$. Voriconazole minimum inhibitory concentrations (MICs) were elevated in 50\% of isolates in two large series from India and the Centers for Disease Control and Prevention (CDC $)^{12,20}$. Posaconazole and isavuconazole show excellent in vitro activity against $C$. auris $^{9,12,14}$. Currently, the drugs of choice for treating fungemia due to $C$. auris are the echinocandins provided that susceptibility testing has been performed ${ }^{22}$. A new drug, SCY-078, which is an orally bioavailable 1,3- $\beta$-Dglucan synthesis inhibitor, exhibits potent activity against $C$. auris isolates and may prove to be an important antifungal in the treatment of MDR species ${ }^{23}$.

The overall crude in-hospital mortality rate of $C$. auris fungemia ranges from 30 to $60 \%^{16,24}$. The rapid emergence of $C$. auris has prompted the CDC in the USA, the European Centre for Disease Prevention and Control, and other institutions to publish alerts and recommendations regarding the control of this notorious fungus ${ }^{25,26}$.

\section{Trichosporon}

Trichosporon species are basidiomycetous yeast-like fungi, are found in soil and freshwater, are part of the human mycobiome, and colonize the skin, the peri-genital areas, and the gastrointestinal tract. Invasive trichosporonosis has been described in patients with leukemia, burns, and AIDS, in patients receiving corticosteroids, and in patients who have undergone heart valve or ophthalmic surgery ${ }^{27-31}$. Trichosporon spp. cause a wide spectrum of infections, ranging from white piedra and hypersensitivity pneumonia in immunocompetent patients to fungemia, endocarditis, peritonitis, and meningitis in patients with hematologic malignancies ${ }^{27,31-34}$. The species most commonly found in fungemias are T. asahii $(75 \%)$, T. mucoides (7\%), T. inkin (5\%), and T. asteroides $(5 \%)^{28}$, but at least 15 other species have been identified from 
clinical samples ${ }^{29}$. Microscopic characteristics are pseudohyphae and septate hyphae along with arthroconidia and blastoconidia.

Diagnosis is made by blood cultures. Species identification relies either on phenotypic methods or on molecular analysis targeting the ribosomal DNA internal transcribed spacer (ITS) region ${ }^{35}$. The rapid MALDI-TOF MS methodology is being increasingly applied and appears to be a promising tool. Molecular methods have also been developed for the detection of Trichosporon spp. in blood and tissues, even in formalin-fixed and paraffin-embedded (FFPE) tissue ${ }^{36}$, but no standardized method exists yet. Crossreactions with the serum Cryptococcus glucuronoxylomannan antigen as well as the Aspergillus galactomannan antigen (GM) have been reported in several cases of Trichosporon fungemia ${ }^{37-39}$, and dual positivity may be suggestive for Trichosporon infection. Serum $\beta$-D-glucan is often detected, but sensitivity is low ${ }^{39}$.

The preferred antifungal for treating trichosporonosis is voriconazole $^{40}$. Posaconazole and other triazoles are also active, and fluconazole shows variable potency ${ }^{40-42}$. Amphotericin $\mathrm{B}$, the echinocandins, and flucytosine are not indicated for treating trichosporonosis. The mortality of disseminated infection remains high (rates of 42 to $77 \%{ }^{27,32,43}$ ).

\section{Magnusiomyces and Saprochaete}

Magnusiomyces capitatus (formerly Geotrichum capitatum, Blastoschizomyces capitatus, or Saprochaete capitata) and Saprochaete clavata (formerly known as Geotrichum clavatum) are human pathogens that are closely related and are frequently mistaken for each other ${ }^{44}$. The taxonomy of Geotrichum was revised relatively recently ${ }^{45}$, but many authors use the older names. With the use of ITS sequencing, isolates are identified as $S$. clavata, $M$. capitatus, or Geotrichum candidum ${ }^{44}$. These fungi are ascomycetous yeasts found in soil, water, plants, poultry feces, and dairy products ${ }^{46-48}$. They may colonize the human skin and mucosae and can cause infections clinically similar to candidiasis. Reports of infections due to $M$. capitatus originate mainly from Europe, mostly from the Mediterranean area ${ }^{43,49,50}$, but there have also been publications from Asia $^{51}$. The majority of cases are seen in patients with underlying hematologic malignancies ${ }^{43,49,52}$. Nosocomial outbreaks have been reported ${ }^{4,53}$. Fungemias due to $S$. clavata are very rare, but a multicenter outbreak was identified by WGS in France ${ }^{54}$. In patients with neutropenia, the disease is disseminated, often presenting with fever and cutaneous lesions. Several organs, including the lung, liver, spleen, bone, kidneys, brain, and endocardium, may be involved ${ }^{50}$. Keratitis ${ }^{55}$, meningitis, and osteomyelitis ${ }^{56}$ may also occur.

Diagnosis is based on blood cultures. Molecular methods are necessary in order make a correct identification ${ }^{44}$. Patients with invasive infection may have a positive GM test, but it is uncertain whether this can be used as a diagnostic tool because invasive aspergillosis may coexist with infection due to Magnusiomyces or Saprochaete ${ }^{57,58}$.

The preferred agent for the treatment of invasive infections is amphotericin $\mathrm{B}$ with or without concomitant flucytosine $\mathrm{e}^{40}$. Voriconazole is active in vitro, and there are case reports where it has been used successfully ${ }^{46,59}$. Mortality of disseminated infection is high, ranging from 50 to $75 \%$ 43,47,60.

\section{Rhodotorula}

Rhodotorula spp. are basidiomycetous yeasts, which are widespread in nature. They are found in air, soil, lakes, seawater, foods, and beverages ${ }^{61}$. They have also been isolated from medical equipment, such as bronchoscopes, and from shower curtains, bathtubs, and toothbrushes ${ }^{62}$. The fungus may colonize the skin, nails, and the respiratory, gastrointestinal, and genital tract of humans ${ }^{63}$.

The culture of Rhodotorula spp. produces distinctive orange to salmon-colored mucoid colonies. The most common species, which may cause invasive infections in humans, are $R$. mucilaginosa (rubra), $R$. glutinis, and $R$. minuta. Infections occur mainly in patients with hematologic or other malignancies and in the majority present as fungemia, which is almost always catheterrelated $^{63-68}$. Other reported infections include endocarditis ${ }^{64,69,70}$, peritonitis (associated with ambulatory peritoneal dialysis) ${ }^{71}$, meningitis ${ }^{72}$, and endophthalmitis ${ }^{67,73}$ and occur in patients with AIDS, extensive burns, or cirrhosis, in those who have undergone intra-abdominal surgery, and in critically ill patients in the $\mathrm{ICU}^{74,75}$

Rhodotorula spp. are resistant in vitro to echinocandins and azoles $^{76,77}$, and there are several cases where fungemia with Rhodotorula emerged in patients receiving prophylaxis with these agents ${ }^{66,78}$. The recommended treatment is amphotericin B with or without flucytosine ${ }^{40}$. CVCs should be removed. Mortality is estimated to be 12 to $20 \%{ }^{63,64}$.

\section{Saccharomyces}

Saccharomyces cerevisiae (also known as "baker's yeast") is a ubiquitous ascomycetous yeast found in soil, plants, and fruit ${ }^{79}$. $S$. boulardii is a strain of $S$. cerevisiae with some specific genome features $^{80,81}$ and is found in some probiotic preparations ${ }^{82,83}$ used in the prevention and treatment of various diarrheal diseases ${ }^{84}$. Saccharomyces has been isolated from the throat, stool, urine, and perineum of patients with hematologic malignancies ${ }^{85}$. It is an emerging cause of invasive fungal infections, either in patients receiving probiotics ${ }^{82,83,86,87}$ or in those with underlying diseases, such as leukemia ${ }^{79}$. There have been reports of nosocomial outbreaks ${ }^{88,89}$, some of them attributed to central catheters or hand transmission ${ }^{88,90}$, but the largest proportion of these fungemias is associated with probiotics ${ }^{79}$. The clinical presentation is the same as that of candidemia. Diagnosis is made by culture and conventional identification methods ${ }^{40}$. In the search for early diagnostic markers, $\beta$-D-glucan has been considered and has been found in the plasma of patients and in culture supernatant ${ }^{91,92}$, but no clinical data are available to prove its usefulness. A novel multiplex real-time polymerase chain reaction (PCR) assay for the detection and differentiation of fungal pathogens in clinical specimens of hematological patients, including Saccharomyces spp., has been developed and seems promising, but validation is still required ${ }^{93}$. Amphotericin B has the lowest MICs for Saccharomyces and is considered the drug of choice for its treatment ${ }^{40}$. There have been reports of successful treatment with echinocandins ${ }^{94,95}$. 
Fluconazole is often inactive. Probiotics should be discontinued and CVCs removed ${ }^{40}$. Mortality of $S$. cerevisiae fungemia was $29.5 \%$ in one study but, in most cases, could not be attributed only to fungemia ${ }^{87}$.

\section{Malassezia}

Malassezia is a genus of basidiomycetous yeasts comprising the lipid-dependent Malassezia furfur and the lipid-independent species Malassezia pachydermatis, which are part of the normal skin microbiota ${ }^{96}$. They can cause skin infections (for example, pityriasis versicolor) as well as systemic infections in neonates receiving lipid-containing parenteral nutrition and in children and adults with hematologic malignancies, cancer, Crohn's disease, and chronic ambulatory peritoneal dialysis ${ }^{97}$. There are multiple reports of outbreaks in neonatal ICUs ${ }^{98-100}$. The clinical signs and symptoms of Malassezia fungemia are non-specific, consisting mainly of fever. Dissemination to the heart, lungs, and other organs may occur ${ }^{101}$. Diagnosis is made by culture but is difficult because routinely used media do not support the growth of this fungus, which requires lipids ${ }^{101}$. The recommended treatment for severe cases is amphotericin B and for non-severe cases fluconazole, although $M$. pachydermatis may be less susceptible in vitro $^{40,97,101}$. The mortality of invasive Malassezia infections is unknown, but it seems that, with appropriate management, the attributable mortality is low ${ }^{101}$.

\section{Rare molds}

Mucormycetes

Mucormycosis is the third most common cause of invasive fungal infection (after candidiasis and aspergillosis). The agents of mucormycosis are ubiquitous in nature and are found mainly in decaying organic matter. They belong to the order Mucorales and include the genera Rhizopus, Rhizomucor, Mucor, Lichtheimia, Apophysomyces, Cunninghamella, Saksenaea, Cokeromyces, Actinomucor, and Syncephalastrum ${ }^{102}$. Some of these genera, such as Saksenaea and Apophysomyces, are more common in certain geographic areas ${ }^{103-105}$. The major risk factors for mucormycosis are uncontrolled diabetes mellitus, hematologic malignancies, organ or bone marrow transplantation, neutropenia, treatment with corticosteroids, trauma and burns, and deferoxamine (an iron/aluminium chelator) therapy ${ }^{106}$. Iron acquisition is a critical step in the pathogenetic mechanism of mucormycosis, and deferoxamine has been shown to act as a siderophore for Mucorales ${ }^{106}$.

Mucorales cause a diverse and devastating spectrum of infections. Rhinocerebral, pulmonary soft tissue, and disseminated disease are the most common clinical presentations, but virtually any organ can be affected ${ }^{107,108}$. The fungi invade the arteries, leading to extensive vessel thrombosis and subsequent infarction ${ }^{106}$. Although tissue necrosis is the hallmark of mucormycosis, a presentation and syndrome-oriented approach to diagnosis lacks sensitivity and specificity. Other fungi, such as Aspergillus or Fusarium, may produce the same clinical signs. Nevertheless, there are some features which should lead to a higher index of suspicion for invasive pulmonary mucormycosis ${ }^{109}$. These include prior prophylaxis with voriconazole or emergence of breakthrough fungal infection in an immunocompromised patient receiving agents active against Aspergillus but not Mucorales. Radiologically, multiple (at least 10) nodules and pleural effusion are more common in mucormycosis. The presence of reverse halo sign on computed tomography is a strong indicator of lung mucormycosis and may appear earlier than other radiologic findings ${ }^{110-112}$.

The diagnosis is traditionally based on direct microscopic examination, histopathology, and culture. Mucorales produce rapidly growing white to gray fluffy colonies with broad hyphae microscopically and a variety of species-specific structures such as stolons, rhizoids, sporangia, apophyses, sporangiophores, columellae, and sporangiospores. The hyphae are large, ribbonlike, irregular pauciseptate or aseptate in contrast with those seen in aspergillosis, which are more regular and septate. However, mucormycosis can be either overdiagnosed or missed by histopathology. In a study of 58 culture-proven mold infections from four tertiary centers using a blinded assessment, Aspergillus spp. infections were misidentified as mucormycosis in $11 \%$ of the cases $^{113}$. In another study, 2 out of 58 cases diagnosed as aspergillosis on histopathology or cytology or both were proven to be mucormycosis by culture ${ }^{114}$. Furthermore, 30 to $50 \%$ of histopathology-proven cases may have negative cultures ${ }^{115,116}$.

Studies have shown that molecular identification of mucormycosis is accurate, using the ITS region of the ribosomal DNA as a first-line sequencing target for the identification of Zygomycete organisms in pure culture ${ }^{117}$. When no culture is available, PCR assays on fresh or FFPE tissues can identify and discriminate between agents of aspergillosis and mucormycosis ${ }^{118-123}$. These techniques are not yet standardized but provide a promising tool for the identification of fungal agents. Detection of circulating Mucorales DNA in serum using real-time PCR is another field of current research and may aid in the earlier diagnosis of the disease $^{124,125}$.

Early diagnosis of mucormycosis is crucial, and prompt therapeutic intervention may prevent progressive tissue invasion and its sequelae ${ }^{109,126}$. Therefore, it is very important to use all available diagnostic methods in order to achieve the best possible outcome. Treatment is multimodal, including antifungal agents, surgical debridement, and reversal of underlying risk factors ${ }^{127,128}$. Mucorales are resistant to most antifungals in vitro. Amphotericin B is the most active drug, except for Cunninghamella and Apophysomyces isolates ${ }^{129,130}$. Posaconazole and isavuconazole are also active, while itraconazole and terbinafine show some activity against certain strains. There seems to be some correlation between the degree of susceptibility of Mucorales isolates to amphotericin $\mathrm{B}$ and outcomes. In a small study by Lamoth et al., an MIC of not more than $0.5 \mu \mathrm{g} / \mathrm{mL}$ was significantly associated with better 6-week outcomes ${ }^{131}$. Liposomal amphotericin B is the drug of choice for first-line treatment. Posaconazole is recommended for salvage or maintenance therapy. Isavuconazole has recently been approved for the treatment of mucormycosis, but its role as first-line treatment has not yet been defined $^{132}$. 
Even with aggressive therapy, the mortality of mucormycosis remains high. For this reason, there is interest in the use of combination treatment or adjunctive modalities. In a recent study, which evaluated the impact of monotherapy versus combination therapy in a group of 106 patients with hematologic malignancies and which used a propensity score analysis, there was no improved outcome for the group receiving combination treatment ${ }^{133}$. Combination of amphotericin B with deferasirox, an iron chelator which does not act as a siderophore for Mucorales, was associated with poorer outcomes in a small prospective study in patients with hematologic malignancies ${ }^{134}$. However, based on preclinical data, there might be a role for this approach in patients with other underlying diseases ${ }^{135}$. Other adjunctive treatments used in the attempt to enhance the outcome of this devastating disease include cytokines and hyperbaric oxygen. Some authors published case reports of successive treatment of mucormycosis with the use of hyperbaric oxygen in combination with antifungal treatment ${ }^{136}$. There are also some data showing that granulocyte-macrophage colony-stimulating factors or interferon-gamma or both may enhance the immune response against certain Mucorales $^{137}$. However, since the data are only in vitro or pre-clinical, these therapies must be used cautiously.

\section{Hyaline molds}

Fusarium. Fusarium species are widely distributed in nature, occurring in ecosystems all around the globe. They are known important plant pathogens ${ }^{138}$ and constitute a large genus with a complex and evolving taxonomy. However, only a few species complexes (SCs), currently 10, are involved in human disease; the most frequent are Fusarium solani, F. oxysporum, F. incarnatumequiseti, F. fujikuroi (including the species $F$. verticillioides, F. proliferatum, and $F$. sacchari), F. clamydosporum, and F. dimerum ${ }^{139,140}$. Depending on the immune status of the host and the portal of entry, they cause a broad spectrum of infections, including superficial, locally invasive, and disseminated infection, and have considerable morbidity and high mortality rates ${ }^{141}$. Some species produce mycotoxins and have a significant impact on animal and human health ${ }^{138}$.

In immunocompetent hosts, Fusarium species, along with Candida and Aspergillus, are considered a leading cause of keratitis. Risk factors include accidental trauma, long-term use of topical corticosteroids and antibiotics, diabetes, pre-existing eye infections, eye surgery ${ }^{142,143}$, and (since the 1980s) contact lens use, with increasing frequency ${ }^{144}$, especially in more developed countries $^{145-148}$. Fusarium keratitis progresses slowly and can cause devastating ocular damage after the formation of penetrating ulcer and endophthalmitis. Therapy consists of topical antifungals, sometimes in combination with subconjunctival injections, but therapeutic keratoplasty may be needed in difficult cases. In many cases, the outcome is poor, especially in delayed diagnosis, and is more favorable in contact lens wearers ${ }^{149}$.

Other forms of fusariosis, including the most prevalent ones in otherwise healthy individuals, are onychomycosis and skin infections, peritonitis following continuous ambulatory peritoneal dialysis, catheter-associated fungemia, and, less frequently, pneumonia, osteomyelitis, arthritis, otitis, sinusitis, and brain abscess, usually after trauma ${ }^{150}$.
In the immunocompromised hosts, those mostly at risk have acute myeloid and acute lymphoid leukemia, and the most important risk factors are neutropenia, lymphopenia, graft-versus-host disease, corticosteroid use, or any other immunosuppressive treatment. Infection is almost always invasive and frequently disseminated ${ }^{151}$. The most common routes of infection are direct inoculation and airborne uptake ${ }^{141}$, and the portals of entry are the paranasal sinuses, the lungs, and skin lesions such as interdigital intertrigo, abnormal appearing nails, and paronychia ${ }^{152,153}$. Disseminated fusariosis is hardly distinguishable from aspergillosis both clinically and histologically, but agents of fusariosis, unlike those of aspergillosis and mucormycosis, can be isolated from blood cultures. It typically presents with fever in severely neutropenic patients and with myalgia and sudden appearance of erythematous, papular, or painful nodular skin lesions which evolve rapidly to central necrosis. The lungs and sinuses can also be affected, and pneumonia occurs in almost $50 \%$ of cases ${ }^{154}$.

According to the few existing epidemiological studies, the incidence appears to be low-less than $0.3 \%$ among allogeneic hematopoietic cell transplantation (HCT) recipients and patients with hematologic malignancies-but variable in different geographic regions $^{155-158}$. The highest incidence is in Brazil: $5.2 \%$ among allogeneic HCT recipients and $3.8 \%$ in patients with acute myeloid leukemia ${ }^{158}$. Hematological patients in this region appeared to have an unusually high incidence of cutaneous portal of entry ${ }^{159,160}$. In previous studies, increased incidence of infection has been associated with hospital water distribution systems which also serve as a potential reservoir of Fusarium spp. ${ }^{3,161}$. The distribution of Fusarium species varies too in different geographic regions, but it seems that any species of Fusarium can cause any type of infection ${ }^{162,163}$.

Diagnosis is based on conventional mycological methodsdirect microscopy, culture, and histopathology $y^{154}$-and has to be as prompt and accurate as possible. However, direct microscopy and histopathology, though highly sensitive, are not specific for Fusarium, as hyphae share the same characteristics with all hyaline molds, such as Aspergillus and Scedosporium.

Culture has low sensitivity, as it can be positive in just $60 \%$ of cases $^{154}$. Identification of a Fusarium isolate to the genus level is easy because of the characteristic banana-shaped macroconidia ${ }^{154}$. However, identification to the species level requires molecular methods, preferably performed in reference laboratories ${ }^{140}$. MALDI-TOF MS appears to be a promising and more feasible approach for the identification of clinical isolates of Fusarium at the species level provided that the existing database is expanded $^{164}$. For direct and rapid detection in tissues and blood, multiplex reverse transcription-PCR methods have recently been developed with promising results ${ }^{140,165}$.

Clinically important species are resistant to almost all currently used antifungals, and this poses a challenge for antifungal therapy ${ }^{166}$. The exact resistance mechanisms in Fusarium have not been elucidated yet, but combinations of CYP51A amino-acid alterations or CYP51A gene overexpression or both might be involved in azole resistance ${ }^{167}$. Amphotericin B has the lowest MICs in vitro, whereas the azoles show variable values with a 
large interspecies variability ${ }^{163}$. Voriconazole appears to be effective in vivo and a good alternative to amphotericin B despite higher $\mathrm{MICs}^{154}$.

Based on the available data, voriconazole or a lipid-based amphotericin B formulation is recommended as primary therapy ${ }^{151,154}$. Combination therapy is frequently used but not scientifically supported. Posaconazole is recommended as salvage therapy ${ }^{151,154}$. A thorough clinical evaluation and treatment of skin lesions, particularly onychomycosis, have been recommended for patients at high risk for invasive fusariosis, prior to or upon initiation of antineoplastic therapy ${ }^{154}$. In addition to antifungal treatment, surgical debridement of infected tissues, removal of venous catheters in confirmed catheter-related fusariosis, and reversal of the immunocompromised state should take place whenever possible for an optimal outcome ${ }^{151,154}$. Prognosis in the immunocompromised is poor and is highly dependent on the underlying condition and immune status of the patient, but survival seems to have substantially increased in the last decade ${ }^{168}$.

Scedosporium and Lomentospora. The hyaline molds known as Scedosporium and Pseudallescheria until 2014 are cosmopolitan saprophytes, commonly found in soil, polluted water, compost, and the manure of cattle and fowl ${ }^{151,169}$. They have a complex taxonomy, hence the nomenclature discrepancies with older studies ${ }^{170-172}$. The most frequent clinically relevant species are Scedosporium boydii, $S$. apiospermum, and $S$. auratiacum. $S$. boydii and $S$. apiospermum are clearly distinct species but, owing to common pathology characteristics and antifungal susceptibility patterns, may be considered a complex and indicated as "S. apiospermum SC" in the routine laboratory, as proposed by de Hoog et al. in 2013"173. The name "Scedosporium" has also been proposed for their teleomorphic stages (sexual forms) Pseudallescheria boydii and P. apiosperma ${ }^{172}$.

Distribution varies according to climate ${ }^{151}$. They cause highly lethal opportunistic infections in immunocompromised patients, but also a wide range of infections in immunocompetent individuals, with considerable morbidity ${ }^{171}$. They are frequently isolated from patients with cystic fibrosis, occasionally causing lung infection ${ }^{174,175}$.

Infections in the immunocompetent occur after penetrating trauma and include keratitis, endophthalmitis, otitis, sinusitis, central nervous system (CNS) infections, osteoarticular and soft tissue infections, and mycetoma ${ }^{176,177}$. Disseminated infections with S. apiospermum/Pseudallescheria and pneumonia or CNS involvement can follow near-drowning accidents in polluted water ${ }^{171,177-185}$. Of note are cases of transplant recipients with previously near-drowning victims as donors ${ }^{186,187}$. In contrast, Lomentospora prolificans (formerly Scedosporium prolificans, or $S$. inflatum) is mainly isolated from cases with underlying immunosupression $^{188}$. Infection can affect any organ, usually the skin, sinuses, lungs, and the CNS, following hematogenous dissemination, and delayed treatment of brain abscesses is associated with a high mortality rate $(>75 \%)^{188}$. This species is also phylogenetically separated from the other Scedosporium species; therefore, the recommendation was recently made to rename it
Lomentospora prolificans $^{172}$ (that is, under its oldest genus name Lomentospora $\left.{ }^{189}\right)$.

As in fusariosis and other mold mycoses, diagnosis is based on direct microscopy, culture, and histopathology, but more sensitive and specific methods are sought for accurate and prompt diagnosis. New molecular methods have recently been developed and are promising for both direct detection and identification to the species level. In infections with $L$. prolificans, blood cultures may be positive in more than $50 \%$ of cases and isolates can be easily differentiated from their $S$. apiospermum counterparts because of their characteristic microscopic morphology with inflated phialides ${ }^{171}$.

Therapy is challenging because of a high rate of resistance to antifungals, and the therapeutic outcome is usually poor in patients with persistent immunosuppression. S. apiospermum is resistant in vitro to amphotericin B and flucytosine, and susceptibility to itraconazole, voriconazole, posaconazole, and the echinocandins is variable. L. prolificans is highly resistant to all antifungals, and mortality rates are as high as $95 \%$ in immunocompromised patients ${ }^{190}$. Voriconazole demonstrates the strongest in vitro activity against this species ${ }^{191}$. There are suggestions of synergistic activity of voriconazole with colistin ${ }^{192}$, terbinafine ${ }^{193-197}$, or caspofungin ${ }^{198}$. Combinations of azoles and terbinafine and sequential azole and terbinafine therapy also appear effective against $L$. prolificans ${ }^{199}$. In general, the management of both $S$. apiospermum SC and $L$. prolificans depends on the underlying condition of the host, and voriconazole has been suggested as first-line treatment ${ }^{200-204}$. In the immunocompromised, therapy is multimodal, and, whenever possible, reversal of the immune suppression, along with surgical debridement of infected tissues, is recommended ${ }^{205,206}$.

Paecilomyces and Purpureocillium. Until recently, the fungal species Paecilomyces variotii and Paecilomyces lilacinus were considered to belong to the same genus, but new taxonomic studies have shown that they are not genetically related, and the latter is now assigned the name Purpureocillium lilacinum ${ }^{207}$. They are found in soil, decaying plant material ${ }^{208-210}$, indoor air, and foods $^{210}$

Paecilomyces infections are associated with almost any organ or system of the human body ${ }^{211}$. The most usual infections in immunocompromised patients are cutaneous, catheter-related, and disseminated infections, pneumonia, cellulitis, fungemia, and pyelonephritis ${ }^{208,209,211-213}$. The most frequent infection caused by Purpureocillium lilacinum is keratitis in otherwise healthy hosts after trauma, surgery, or prolonged contact lens use ${ }^{214}$.

Diagnosis is based on conventional mycological methods. MALDI-TOF MS analysis is a promising tool, as with all of the above-described fungi, but requires further cutoff standardization and a reliable reference library ${ }^{215}$. There is no optimal antifungal treatment established. P. lilacinum strains are highly resistant to amphotericin B but susceptible to azoles, whereas $P$. variotii is usually amphotericin B susceptible ${ }^{151}$. 


\section{Dematiaceous (or melanized) molds}

These fungi are darkly pigmented because of the presence of melanin in the cell wall, which acts as a virulence factor ${ }^{216-218}$. More than 70 genera are implicated in human disease; Alternaria, Aureobasidium, Bipolaris, Cladophialophora, Curvularia, Exophiala, Exserohilum, Hortaea werneckii, Neoscytalidium dimidiatum, Ochroconis, and Rhinocladiella are some of the most known representatives ${ }^{219}$.

Commonly found in soil and plant material, they are distributed worldwide, although some neurotropic fungi are often geographically restricted: Rhinocladiella mackenziei occur in the Middle East and Cladophialophora bantiana occur mainly in India, whereas cases of Exophiala dermatitidis are reported mainly from East Asia ${ }^{220}$. They cause phaeohyphomycosis, a term that refers to a broad range of diseases ranging from allergic sinusitis to superficial and disseminated infections, pneumonia, brain abscess $^{220}$, and even iatrogenic infections, such as the 2012-2013 multistate (USA) fungal meningitis epidemic due to Exserohilum rostratum $^{221}$. Infections can be life-threatening in both immunocompromised and immunocompetent individuals. Diagnosis is based on conventional mycological methods and PCR. There are no standardized therapies, but voriconazole, posaconazole, and itraconazole demonstrate the most consistent in vitro activity against this group of fungi. Voriconazole may be superior for CNS infections. Surgery is required for local infections and brain abscesses $^{220}$

\section{Rare and emerging dimorphic fungi \\ Emmonsia-like fungi and Emergomyces}

The genus Emmonsia makes up part of the Ajellomycetaceae family of the Onygenales order, along with the genera Blastomyces, Histoplasma, and Paracoccidioides, among others. Until recently, two species were recognized-E. crescens and E. parvawhich cause adiaspiromycosis, a granulomatous pulmonary disease of rodents and other small mammals and very rarely of humans, through conversion into large, thick-walled "adiaspores" in the infection sites ${ }^{222,223}$. However, in recent years, there has been an increase in cases of diseases caused by novel Emmonsialike species. The increase between 2006 and 2015 was primarily driven by the recognition of HIV-associated cases in South Africa following the introduction of molecular identification protocols for dimorphic fungal infections in $2008^{223}$. These new species differ from the "classical" ones (E. crescens and E. parva) in that they are able to convert into yeast-like cells capable of replication and extra-pulmonary dissemination during the course of infection, instead of the non-replicating adiaspores ${ }^{223}$. Infection probably occurs through the inhalation of spores, but the environmental niche is as yet unknown. New taxonomic research suggests some putative virulence factors that may play a role in the infection and pathogenicity of the novel Emmonsia strains, but these findings need further investigation ${ }^{224}$. The species Emmonsia pasteuriana $^{225-227}$ has now been classified in a new genus of the Ajellomycetaceae family, Emergomyces (Emergomyces pasteurianus comb. nov. $)^{228}$.

Clinical diagnosis of infections due to Emmonsia-like species is difficult because of the protean nature of symptoms and signs. Infections usually are disseminated involving primarily the skin and lungs and frequently are misdiagnosed as tuberculosis. Cutaneous manifestations may be misdiagnosed as varicella, Kaposi's sarcoma, and drug reactions ${ }^{229}$. Laboratory diagnosis is made by biopsy of the skin or any other involved organ and blood culture, although histopathologic findings are not sufficient to distinguish Emmonsia or Emergomyces sp. from other dimorphic fungi. In culture, the above genera are hard to identify by morphological methods alone, and molecular identification is imperative for accurate diagnosis. Urine Histoplasma antigen may aid diagnosis because of high cross-reactivity ${ }^{229}$. Emmonsia-like infections are highly lethal if untreated, the most effective drug being amphotericin $\mathrm{B}^{229}$, although some azoles appear to have variably low MICs in vitro ${ }^{222}$.

Es. pasteurianus and other Emergomyces species (Es. africanus and Es. orientalis) isolated from sporadic cases in different countries such as Italy, Spain, China, Canada, South Africa, and Germany underline the potential of Emergomyces species as new cosmopolitan opportunistic pathogens in the immunocompromised host ${ }^{228}$

\section{Talaromyces (Penicillium) marneffei}

Talaromyces marneffei (formerly Penicillium marneffei), recently renamed on the basis of new sequence data ${ }^{230}$, has been recognized as a significant human pathogen across Southeast Asia with the global AIDS pandemic ${ }^{231}$ and represents an "AIDSdefining pathogen" in this region ${ }^{232,233}$. However, in recent years, improved treatment of HIV infection with highly active antiretroviral therapy and control of HIV/AIDS because of improvement in the healthcare systems of developing countries in that region, such as mainland China, Thailand, and Vietnam, have led to a change in the epidemiology of T. marneffei infection, and there is an increasing number in immunocompromised non-HIV-infected patients ${ }^{234}$. These are usually patients receiving immunosuppressive therapies associated with transplantation or autoimmune diseases and hematology patients treated with novel targeted therapies, including anti-CD20 monoclonal antibodies and kinase inhibitors ${ }^{234-236}$, but also patients with primary adult-onset immunodeficiency due to anti-interferon-gamma auto-antibodies ${ }^{237}$. A donor-related transmission in a lung transplant recipient was also recently reported ${ }^{238}$. Bamboo rats are considered the only identified natural reservoir so far, and transmission is believed to occur through conidia inhalation ${ }^{234,235}$. As patients with penicilliosis may present all over the world following global travelling, a good travel history is essential for clinical diagnosis ${ }^{239}$.

The symptoms include fever, weight loss, anemia, lymphadenopathy, hepatosplenomegaly, respiratory signs, and often molluscum contagiosum-like skin lesions mostly on the face and neck, described as translucent papules, umbilicated with a central necrotic depression ${ }^{235,240}$. However, clinical diagnosis is challenging, especially in the absence of skin lesions and in non-HIV patients.

Laboratory diagnosis is based on histopathology, direct microscopy, and cultures. Blood cultures are frequently positive, and bone marrow cultures are positive in nearly all cases ${ }^{241}$. The 
morphological identification is based on the characteristic colony of the mold phase of the fungus at $25^{\circ} \mathrm{C}$ with red pigment in the agar and yeast-like arthroconidia in the Gram stain of cultures at $37^{\circ} \mathrm{C}$. This finding is crucial, as T. marneffei is the only dimorphic fungus in the Talaromyces genus. New techniques with much shorter turn-around times, such as real-time PCR and MALDI-TOF, are being developed with promising results ${ }^{242,243}$, but, as with the other rare fungi, increased sensitivity and an expanded database are required in order for them to be introduced into routine practice.

The treatment of choice is intravenous amphotericin B (liposomal formulation 3 to $5 \mathrm{mg} / \mathrm{kg}$ per day or lipid complex formulation $5 \mathrm{mg} / \mathrm{kg}$ per day) for 2 weeks, followed by oral itraconazole (400 mg/day) for 10 weeks; alternatively, voriconazole can be used $(6 \mathrm{mg} / \mathrm{kg}$ twice a day on day 1 , followed by $4 \mathrm{mg} / \mathrm{kg}$ twice a day for at least 12 weeks $)^{244,245}$.

\section{Conclusions}

Rare fungal infectious agents have emerged as important pathogens in recent years because of the expanding population of immunocompromised patients. These fungi are ubiquitous saprobes or plant pathogens and lurk to invade any vulnerable host. The infections they cause are associated with high morbidity and mortality, whereas diagnosis and treatment are challenging.
Early diagnosis is of paramount importance but requires a high index of clinical suspicion and accurate diagnostic methods. Conventional diagnostic methods such as direct microscopy, cultures, and histopathology are still essential, but rapid and more specific molecular techniques are needed for early targeted treatment. The currently used PCR-based methods and others, such as MALDI-TOF MS, appear promising but need optimization.

The management of invasive fungal infections is multimodal, and, whenever feasible, surgical debridement and reversal of risk factors are recommended. The efficacy of various antifungals is not uniform, and many of these infectious agents are intrinsically resistant to multiple drugs; in addition, recommendations are mainly based on clinical case experience. Combination treatment, though recommended as salvage therapy in some infections, is controversial in most cases. Despite the use of available antifungals, mortality remains high.

\section{Competing interests}

The authors declare that they have no competing interests.

\section{Grant information}

The author(s) declared that no grants were involved in supporting this work.
1. Arendrup MC, Bruun B, Christensen JJ, et al.: National surveillance of fungemia in Denmark (2004 to 2009). J Clin Microbiol. 2011; 49(1): 325-34. PubMed Abstract | Publisher Full Text | Free Full Text

2. Chitasombat MN, Kofteridis DP, Jiang Y, et al:: Rare opportunistic (non-Candida, non-Cryptococcus) yeast bloodstream infections in patients with cancer. J Infect. 2012; 64(1): 68-75.

PubMed Abstract | Publisher Full Text | Free Full Text

3. F Azie N, Neofytos D, Pfaller M, et al:: The PATH (Prospective Antifungal Therapy) Alliance ${ }^{\circ}$ registry and invasive fungal infections: update 2012. Diagn Microbiol Infect Dis. 2012; 73(4): 293-300.

PubMed Abstract | Publisher Full Text | F1000 Recommendation

4. Satoh K, Makimura K, Hasumi $Y$, et al.: Candida auris sp. nov., a novel ascomycetous yeast isolated from the external ear canal of an inpatient in a Japanese hospital. Microbiol Immunol. 2009; 53(1): 41-4. PubMed Abstract | Publisher Full Text

5. Lee WG, Shin JH, Uh Y, et al: First three reported cases of nosocomial fungemia caused by Candida auris. J Clin Microbiol. 2011; 49(9): 3139-42. PubMed Abstract | Publisher Full Text | Free Full Text

6. Chowdhary A, Sharma C, Duggal S, et al:: New clonal strain of Candida auris, Delhi, India. Emerg Infect Dis. 2013; 19(10): 1670-3. PubMed Abstract | Publisher Full Text | Free Full Text

7. F Chakrabarti A, Sood P, Rudramurthy SM, et al:: Incidence, characteristics and outcome of ICU-acquired candidemia in India. Intensive Care Med. 2015; 41(2): 285-95.

PubMed Abstract | Publisher Full Text | F1000 Recommendation

8. Chowdhary A, Anil Kumar V, Sharma C, et al:: Multidrug-resistant endemic clonal strain of Candida auris in India. Eur J Clin Microbiol Infect Dis. 2014; 33(6): 919-26.

PubMed Abstract | Publisher Full Text

9. Magobo RE, Corcoran C, Seetharam S, et al:: Candida auris-associated candidemia, South Africa. Emerg Infect Dis. 2014; 20(7): 1250-1. PubMed Abstract | Publisher Full Text | Free Full Text

10. Emara M, Ahmad S, Khan Z, et al.: Candida auris candidemia in Kuwait, 2014. Emerg Infect Dis. 2015; 21(6): 1091-2.

PubMed Abstract | Publisher Full Text | Free Full Text
11. Vallabhaneni S, Kallen A, Tsay S, et al:: Investigation of the First Seven Reported Cases of Candida auris, a Globally Emerging Invasive, MultidrugResistant Fungus - United States, May 2013-August 2016. MMWR Morb Mortal Wkly Rep. 2016; 65(44): 1234-7. PubMed Abstract | Publisher Full Text

12. F Lockhart SR, Etienne KA, Vallabhaneni S, et al:: Simultaneous Emergence of Multidrug-Resistant Candida auris on 3 Continents Confirmed by WholeGenome Sequencing and Epidemiological Analyses. Clin Infect Dis. 2017; 64(2) 134-40.

PubMed Abstract | Publisher Full Text | Free Full Text | F1000 Recommendation

13. F Morales-López SE, Parra-Giraldo CM, Ceballos-Garzón A, et al:: Invasive Infections with Multidrug-Resistant Yeast Candida auris, Colombia. Emerg Infect Dis. 2017; 23(1): 162-4.

PubMed Abstract | Publisher Full Text | Free Full Text | F1000 Recommendation

14. F Ruiz Gaitán AC, Moret A, López Hontangas JL, et al.: Nosocomial fungemia by Candida auris: First four reported cases in continental Europe. Rev Iberoam Micol. 2017; 34(1): 23-7.

PubMed Abstract | Publisher Full Text | F1000 Recommendation

15. F Ben-Ami R, Berman J, Novikov A, et al:: Multidrug-Resistant Candida haemulonii and C. auris, Tel Aviv, Israel. Emerg Infect Dis. 2017; 23(1): 195-203. PubMed Abstract | Publisher Full Text | Free Full Text | F1000 Recommendation

16. Schelenz S, Hagen F, Rhodes JL, et al:: First hospital outbreak of the globally emerging Candida auris in a European hospital. Antimicrob Resist Infect Control. 2016; 5: 35.

PubMed Abstract | Publisher Full Text | Free Full Text

17. Tsay S, Welsh RM, Adams EH, et al:: Notes from the Field: Ongoing Transmission of Candida auris in Health Care Facilities - United States, June 2016-May 2017. MMWR Morb Mortal Wkly Rep. 2017; 66(19): 514-5. PubMed Abstract | Publisher Full Text

18. F Sharma C, Kumar N, Pandey R, et al:: Whole genome sequencing of emerging multidrug resistant Candida auris isolates in India demonstrates low genetic variation. New Microbes New Infect. 2016; 13: 77-82. PubMed Abstract | Publisher Full Text | Free Full Text | F1000 Recommendation

19. F Chatterjee S, Alampalli SV, Nageshan RK, et al:: Draft genome of a 
commonly misdiagnosed multidrug resistant pathogen Candida auris. BMC Genomics. 2015; 16: 686 .

PubMed Abstract | Publisher Full Text | Free Full Text | F1000 Recommendation

20. Kathuria S, Singh PK, Sharma C, et al:: Multidrug-Resistant Candida auris Misidentified as Candida haemulonii: Characterization by Matrix-Assisted Laser Desorption lonization-Time of Flight Mass Spectrometry and DNA Sequencing and Its Antifungal Susceptibility Profile Variability by Vitek 2, CLSI Broth Microdilution, and Etest Method. J Clin Microbiol. 2015; 53(6): 1823-30. PubMed Abstract | Publisher Full Text | Free Full Text

21. Mizusawa M, Miller H, Green R, et al.: Can Multidrug-Resistant Candida auris Be Reliably Identified in Clinical Microbiology Laboratories? J Clin Microbiol. 2017; 55(2): 638-40.

PubMed Abstract | Publisher Full Text | Free Full Text

22. Chowdhary A, Sharma C, Meis JF: Candida auris: A rapidly emerging cause of hospital-acquired multidrug-resistant fungal infections globally. PLOS Pathog. 2017; 13(5): e1006290.

PubMed Abstract | Publisher Full Text | Free Full Text

23. F Larkin E, Hager C, Chandra J, et al:: The Emerging Pathogen Candida auris: Growth Phenotype, Virulence Factors, Activity of Antifungals, and Effect of SCY-078, a Novel Glucan Synthesis Inhibitor, on Growth Morphology and Biofilm Formation. Antimicrob Agents Chemother. 2017; 61(5): pii: e02396-16. PubMed Abstract | Publisher Full Text | Free Full Text | F1000 Recommendation

24. Calvo B, Melo AS, Perozo-Mena A, et al:: First report of Candida auris in America: Clinical and microbiological aspects of 18 episodes of candidemia. $J$ Infect. 2016; 73(4): 369-74.

PubMed Abstract | Publisher Full Text

25. CDC: Candida auris interim recommendations for healthcare facilities and laboratories. Atlanta, GA: US Department of Health and Human Services, CDC 2017.

Reference Source

26. European Centre for Disease Prevention and Control: Candida auris in healthcare settings. - Europe - 19 December 2016. Stockholm: ECDC; 2016. Reference Source

27. Kontoyiannis DP, Torres HA, Chagua M, et al.: Trichosporonosis in a tertiary care cancer center: risk factors, changing spectrum and determinants of outcome. Scand J Infect Dis. 2004; 36(8): 564-9.

PubMed Abstract | Publisher Full Text

28. F Liao Y, Lu X, Yang S, et al.: Epidemiology and Outcome of Trichosporon Fungemia: A Review of 185 Reported Cases From 1975 to 2014. Open Forum Infect Dis. 2015; 2(4): ofv141.

PubMed Abstract | Publisher Full Text | Free Full Text | F1000 Recommendation

29. $F$ de Almeida Júnior JN, Hennequin C: Invasive Trichosporon Infection: a Systematic Review on a Re-emerging Fungal Pathogen. Front Microbiol. 2016; 7: 1629

PubMed Abstract | Publisher Full Text | Free Full Text | F1000 Recommendation

30. Piérard GE, Read D, Piérard-Franchimont $C$, et al:: Cutaneous manifestations in systemic trichosporonosis. Clin Exp Dermatol. 1992; 17(2): 79-82. PubMed Abstract | Publisher Full Text

31. Colombo AL, Padovan AC, Chaves GM: Current knowledge of Trichosporon spp. and Trichosporonosis. Clin Microbiol Rev. 2011; 24(4): 682-700. PubMed Abstract | Publisher Full Text | Free Full Text

32. Ruan SY, Chien JY, Hsueh PR: Invasive trichosporonosis caused by Trichosporon asahii and other unusual Trichosporon species at a medical center in Taiwan. Clin Infect Dis. 2009; 49(1): e11-7. PubMed Abstract | Publisher Full Text

33. F Kumar A, Udayakumaran S, Babu R, et al:: Trichosporon asahii infection presenting as chronic meningo-ventriculitis and intra ventricular fungal ball: a case report and literature review. Mycoses. 2015; 58(2): 99-103. PubMed Abstract | Publisher Full Text | F1000 Recommendation

34. Chen YT, Yang WC, Chen TW, et al.: Trichosporon mucoides peritonitis in a continuous ambulatory peritoneal dialysis patient. Perit Dial Int. 2013; 33(3): 341-2.

PubMed Abstract | Publisher Full Text | Free Full Text

35. Rastogi V, Honnavar P, Rudramurthy SM, et al:: Molecular characterisation and antifungal susceptibility of clinical Trichosporon isolates in India. Mycoses. 2016; 59(8): 528-34.

PubMed Abstract | Publisher Full Text

36. Shinozaki M, Okubo Y, Sasai D, et al.: Development of a peptide nucleic acid probe to Trichosporon species and identification of trichosporonosis by use of in situ hybridization in formalin-fixed and paraffin-embedded (FFPE) sections. J Clin Microbiol. 2013; 51(1): 295-8.

PubMed Abstract | Publisher Full Text | Free Full Text

37. Melcher GP, Reed KD, Rinaldi MG, et al.: Demonstration of a cell wall antigen cross-reacting with cryptococcal polysaccharide in experimental disseminated trichosporonosis. J Clin Microbiol. 1991; 29(1): 192-6. PubMed Abstract | Free Full Text

38. Fekkar A, Brun S, D'Ussel M, et al:: Serum cross-reactivity with Aspergillus galactomannan and cryptococcal antigen during fatal disseminated Trichosporon dermatis infection. Clin Infect Dis. 2009; 49(9): 1457-8. PubMed Abstract | Publisher Full Text

39. Liao $\mathrm{Y}$, Hartmann $\mathrm{T}$, Ao JH, et al:: Serum glucuronoxylomannan may be more appropriate for the diagnosis and therapeutic monitoring of Trichosporon fungemia than serum $\beta$-D-glucan. Int J Infect Dis. 2012; 16(8): e638. PubMed Abstract | Publisher Full Text

40. Arendrup MC, Boekhout T, Akova M, et al:: ESCMID and ECMM joint clinica guidelines for the diagnosis and management of rare invasive yeast infections. Clin Microbiol Infect. 2014; 20 Suppl 3: 76-98. PubMed Abstract | Publisher Full Text

41. Hazirolan G, Canton E, Sahin S, et al:: Head-to-head comparison of inhibitory and fungicidal activities of fluconazole, itraconazole, voriconazole, posaconazole, and isavuconazole against clinical isolates of Trichosporon asahii. Antimicrob Agents Chemother. 2013; 57(10): 4841-7. PubMed Abstract | Publisher Full Text | Free Full Text

42. Tsai MS, Yang YL, Wang AH, et al.: Susceptibilities to amphotericin B, fluconazole and voriconazole of Trichosporon clinical isolates. Mycopathologia. 2012; 174(2): 121-30.

PubMed Abstract | Publisher Full Text

43. Girmenia C, Pagano L, Martino B, et al:: Invasive infections caused by Trichosporon species and Geotrichum capitatum in patients with hematological malignancies: a retrospective multicenter study from Italy and review of the literature. J Clin Microbiol. 2005; 43(4): 1818-28.

PubMed Abstract | Publisher Full Text | Free Full Text

44. Desnos-Ollivier M, Blanc C, Garcia-Hermoso D, et al: Misidentification of Saprochaete clavata as Magnusiomyces capitatus in clinical isolates: utility of internal transcribed spacer sequencing and matrix-assisted laser desorption ionization-time of flight mass spectrometry and importance of reliable databases. J Clin Microbiol. 2014; 52(6): 2196-8.

PubMed Abstract | Publisher Full Text | Free Full Text

45. De Hoog GS, Smith MT: Ribosomal gene phylogeny and species delimitation in Geotrichum and its teleomorphs. Stud Mycol. 2004; 50: 489-515. Reference Source

46. Bouza E, Muñoz P: Invasive infections caused by Blastoschizomyces capitatus and Scedosporium spp. Clin Microbiol Infect. 2004; 10 Suppl 1: 76-85. PubMed Abstract | Publisher Full Text

47. Gurgui M, Sanchez F, March F, et al:: Nosocomial outbreak of Blastoschizomyces capitatus associated with contaminated milk in a haematological unit. $J$ Hosp Infect. 2011; 78(4): 274-8. PubMed Abstract | Publisher Full Text

48. Pottier I, Gente S, Vernoux JP, et al:: Safety assessment of dairy microorganisms: Geotrichum candidum. Int J Food Microbiol. 2008; 126(3): 327-32. PubMed Abstract | Publisher Full Text

49. Martino R, Salavert M, Parody R, et al.: Blastoschizomyces capitatus infection in patients with leukemia: report of 26 cases. Clin Infect Dis. 2004; 38(3): 335-41. PubMed Abstract | Publisher Full Text

50. Birrenbach T, Bertschy S, Aebersold F, et al.: Emergence of Blastoschizomyces capitatus yeast infections, Central Europe. Emerging Infect Dis. 2012; 18(1): 98-101. PubMed Abstract | Publisher Full Text | Free Full Text

51. F Subramanya Supram H, Gokhale S, Chakrabarti A, et al.: Emergence of Magnusiomyces capitatus infections in Western Nepal. Med Mycol. 2016; 54(2): 103-10.

PubMed Abstract | Publisher Full Text | F1000 Recommendation

52. García-Ruiz JC, López-Soria L, Olazábal I, et al:: Invasive infections caused by Saprochaete capitata in patients with haematological malignancies: report of five cases and review of the antifungal therapy. Rev Iberoam Micol. 2013; 30(4): 248-55.

PubMed Abstract | Publisher Full Text

53. D'Antonio D, Mazzoni A, lacone A, et al:: Emergence of fluconazole-resistant strains of Blastoschizomyces capitatus causing nosocomial infections in cancer patients. J Clin Microbiol. 1996; 34(3): 753-5. PubMed Abstract | Free Full Text

54. Vaux S, Criscuolo A, Desnos-Ollivier M, et al.: Multicenter outbreak of infections by Saprochaete clavata, an unrecognized opportunistic fungal pathogen. $\mathrm{mBio}$. 2014; 5(6): pii: e02309-14

PubMed Abstract | Publisher Full Text | Free Full Text

55. Levy J, Benharroch D, Peled N, et al:: Blastoschizomyces capitatus keratitis and melting in a corneal graft. Can J Ophthalmol. 2006; 41(6): 772-4.

PubMed Abstract | Publisher Full Text

56. Celik AD, Ozaras R, Kantarcioglu S, et al:: Spondylodiscitis due to an emergent fungal pathogen: Blastoschizomyces capitatus, a case report and review of the literature. Rheumatol Int. 2009; 29(10): 1237-41.

PubMed Abstract | Publisher Full Text

57. Giacchino M, Chiapello N, Bezzio S, et al:: Aspergillus galactomannan enzymelinked immunosorbent assay cross-reactivity caused by invasive Geotrichum capitatum. J Clin Microbiol. 2006; 44(9): 3432-4. PubMed Abstract | Publisher Full Text | Free Full Text

58. Bonini A, Capatti C, Parmeggiani M, et al.: Galactomannan detection in Geotrichum capitatum invasive infections: report of 2 new cases and review of diagnostic options. Diagn Microbiol Infect Dis. 2008; 62(4): 450-2. PubMed Abstract | Publisher Full Text

59. F Devadas SK, Bhat V, Khattry N: Subcutaneous infection caused by Blastoschizomyces capitatus post allogeneic hematopoietic transplant and its successful treatment with voriconazole. Transpl Infect Dis. 2015; 17(4): 588-92. PubMed Abstract | Publisher Full Text | F1000 Recommendation

60. Mazzocato S, Marchionni E, Fothergill AW, et al.: Epidemiology and outcome of 
systemic infections due to saprochaete capitata: case report and review of the literature. Infection. 2015; 43(2): 211-5.

PubMed Abstract | Publisher Full Text

61. Wirth F, Goldani LZ: Epidemiology of Rhodotorula: an emerging pathogen. Interdiscip Perspect Infect Dis. 2012; 2012: 465717.

PubMed Abstract | Publisher Full Text | Free Full Text

62. Hagan ME, Klotz SA, Bartholomew W, et al:: A pseudoepidemic of Rhodotorula rubra: a marker for microbial contamination of the bronchoscope. Infect Control Hosp Epidemiol. 1995; 16(12): 727-8.

PubMed Abstract | Publisher Full Text

63. De Almeida GM, Costa SF, Melhem M, et al:: Rhodotorula spp. isolated from blood cultures: clinical and microbiological aspects. Med Mycol. 2008; 46(6): 547-56.

PubMed Abstract | Publisher Full Text

64. Tuon FF, Costa SF: Rhodotorula infection. A systematic review of $\mathbf{1 2 8}$ cases from literature. Rev Iberoam Micol. 2008; 25(3): 135-40. PubMed Abstract | Publisher Full Text

65. Lo Re V, Fishman NO, Nachamkin I: Recurrent catheter-related Rhodotorula rubra infection. Clin Microbiol Infect. 2003; 9(8): 897-900. PubMed Abstract | Publisher Full Text

66. Lunardi LW, Aquino VR, Zimerman RA, et al.: Epidemiology and outcome of Rhodotorula fungemia in a tertiary care hospital. Clin Infect Dis. 2006; 43(6): e60-3.

PubMed Abstract | Publisher Full Text

67. Tuon FF, de Almeida GM, Costa SF: Central venous catheter-associated fungemia due to Rhodotorula spp. --a systematic review. Med Mycol. 2007; 45(5): 441-7.

PubMed Abstract | Publisher Full Text

68. Kim HA, Hyun M, Ryu SY: Catheter-Associated Rhodotorula mucilaginosa Fungemia in an Immunocompetent Host. Infect Chemother. 2013; 45(3): 339-42. PubMed Abstract | Publisher Full Text | Free Full Text

69. Simon MS, Somersan S, Singh HK, et al.: Endocarditis caused by Rhodotorula infection. J Clin Microbiol. 2014; 52(1): 374-8.

PubMed Abstract | Publisher Full Text | Free Full Text

70. Maeder M, Vogt PR, Schaer G, et al:: Aortic homograft endocarditis caused by Rhodotorula mucilaginosa. Infection. 2003; 31(3): 181-3.

PubMed Abstract

71. Soylu A, Demircioğlu F, Türkmen M, et al:: Unusual cause of peritonitis during peritoneal dialysis. Rhodotorula rubra and amphotericin B. Pediatr Nephrol. 2004; 19(12): 1426-8.

PubMed Abstract | Publisher Full Text

72. Tsiodras S, Papageorgiou S, Meletiadis J, et al:: Rhodotorula mucilaginosa associacted meningitis: A subacute entity with high mortality. Case report and review. Med Mycol Case Rep. 2014; 6: 46-50.

PubMed Abstract | Publisher Full Text | Free Full Text

73. Merkur $A B$, Hodge WG: Rhodotorula rubra endophthalmitis in an HIV positive patient. Br J Ophthalmol. 2002; 86(12): 1444-5

PubMed Abstract | Publisher Full Text | Free Full Text

74. Spiliopoulou A, Anastassiou ED, Christofidou M: Rhodotorula fungemia of an intensive care unit patient and review of published cases. Mycopathologia. 2012; 174(4): 301-9.

PubMed Abstract | Publisher Full Text

75. Villar JM, Velasco CG, Delgado JD: Fungemia due to Rhodotorula mucilaginosa in an immunocompetent, critically ill patient. $J$ Infect Chemother. 2012; 18(4): $581-3$.

PubMed Abstract | Publisher Full Text

76. Gomez-Lopez A, Mellado E, Rodriguez-Tudela JL, et al: Susceptibility profile of 29 clinical isolates of Rhodotorula spp. and literature review. J Antimicrob of 29 clinical isolates of Rhodoto PubMed Abstract | Publisher Full Tex

77. F Diekema DJ, Petroelje B, Messer SA, et al:: Activities of available and investigational antifungal agents against Rhodotorula species. J Clin Microbiol. 2005; 43(1): 476-8.

PubMed Abstract | Publisher Full Text | Free Full Text | F1000 Recommendation

78. Mori T, Nakamura Y, Kato J, et al:: Fungemia due to Rhodotorula mucilaginosa after allogeneic hematopoietic stem cell transplantation. Transpl Infect Dis. 2012; 14(1): 91-4.

PubMed Abstract | Publisher Full Text

79. Enache-Angoulvant A, Hennequin C: Invasive Saccharomyces infection: a comprehensive review. Clin Infect Dis. 2005; 41(11): 1559-68. PubMed Abstract | Publisher Full Text

80. Edwards-Ingram L, Gitsham P, Burton N, et al.: Genotypic and physiological characterization of Saccharomyces boulardii, the probiotic strain of Saccharomyces cerevisiae. Appl Environ Microbiol. 2007; 73(8): 2458-67. PubMed Abstract | Publisher Full Text | Free Full Text

81. McCullough MJ, Clemons KV, McCusker JH, et al:: Species identification and virulence attributes of Saccharomyces boulardii (nom. inval.). J Clin Microbiol. 1998; 36(9): 2613-7.

PubMed Abstract | Free Full Text

82. Thygesen JB, Glerup H, Tarp B: Saccharomyces boulardii fungemia caused by treatment with a probioticum. BMJ Case Rep. 2012; 2012: pii: bcr0620114412. PubMed Abstract | Publisher Full Text | Free Full Text
83. Stefanatou E, Kompoti M, Paridou A, et al:: Probiotic sepsis due to Saccharomyces fungaemia in a critically ill burn patient. Mycoses. 2011; 54(5): e643-6. PubMed Abstract | Publisher Full Text

84. Salonen JH, Richardson MD, Gallacher K, et al:: Fungal colonization of haematological patients receiving cytotoxic chemotherapy: emergence of azole-resistant Saccharomyces cerevisiae. J Hosp Infect. 2000; 45(4): 293-301. PubMed Abstract | Publisher Full Text

85. Marteau PR, de Vrese M, Cellier CJ, et al:: Protection from gastrointestinal diseases with the use of probiotics. Am J Clin Nutr. 2001; 73(2 Suppl): 430S-6. PubMed Abstract

86. Lherm $\mathrm{T}$, Monet $\mathrm{C}$, Nougière $\mathrm{B}$, et al:: Seven cases of fungemia with Saccharomyces boulardii in critically ill patients. Intensive Care Med. 2002; 28(6): 797-801.

PubMed Abstract | Publisher Full Text

87. Muñoz $P$, Bouza E, Cuenca-Estrella M, et al:: Saccharomyces cerevisiae fungemia: an emerging infectious disease. Clin Infect Dis. 2005; 40(11): 1625-34. PubMed Abstract | Publisher Full Text

88. Cassone M, Serra P, Mondello F, et al.: Outbreak of Saccharomyces cerevisiae subtype boulardii fungemia in patients neighboring those treated with a probiotic preparation of the organism. J Clin Microbiol. 2003; 41(11): 5340-3. PubMed Abstract | Publisher Full Text | Free Full Text

89. Olver WJ, James SA, Lennard A, et al:: Nosocomial transmission of Saccharomyces cerevisiae in bone marrow transplant patients. $J$ Hosp Infect. 2002; 52(4): 268-72.

PubMed Abstract | Publisher Full Text

90. Hennequin C, Kauffmann-Lacroix C, Jobert A, et al:: Possible role of catheters in Saccharomyces boulardii fungemia. Eur J Clin Microbiol Infect Dis. 2000; 19(1) 16-20.

PubMed Abstract | Publisher Full Text

91. Yoshida M, Obayashi T, Iwama A, et al.: Detection of plasma (1 --> 3)-beta-D-glucan in patients with Fusarium, Trichosporon, Saccharomyces and Acremonium fungaemias. J Med Vet Mycol. 1997; 35(5): 371-4.

PubMed Abstract | Publisher Full Tex

92. Odabasi Z, Paetznick VL, Rodriguez JR, et al.: Differences in beta-glucan levels in culture supernatants of a variety of fungi. Med Mycol. 2006; 44(3): 267-72. PubMed Abstract | Publisher Full Text

93. F Rahn S, Schuck A, Kondakci M, et al:: A novel comprehensive set of fungal Real time PCR assays (fuPCR) for the detection of fungi in immunocompromised haematological patients-A pilot study. Int $\mathrm{J} \mathrm{Med}$ Microbiol. 2016; 306(8): 611-23.

PubMed Abstract | Publisher Full Text | F1000 Recommendation

94. Lolis N, Veldekis D, Moraitou H, et al:: Saccharomyces boulardii fungaemia in an intensive care unit patient treated with caspofungin. Crit Care. 2008; 12(2): 414 PubMed Abstract | Publisher Full Text | Free Full Text

95. Choi G, Meijer SL, Hazenberg MD: Disseminated bread yeast fungaemia in a baker's wife with acute myeloid leukaemia. Br J Haematol. 2012; 158(3): 298. PubMed Abstract | Publisher Full Text

96. $\mathrm{F}$ Findley $\mathrm{K}, \mathrm{Oh} \mathrm{J}$, Yang J, et al.: Topographic diversity of fungal and bacterial communities in human skin. Nature. 2013; 498(7454): 367-70. PubMed Abstract | Publisher Full Text | Free Full Text | F1000 Recommendation

97. Gaitanis G, Magiatis $\mathrm{P}$, Hantschke $\mathrm{M}$, et al:: The Malassezia genus in skin and systemic diseases. Clin Microbiol Rev. 2012; 25(1): 106-41.

PubMed Abstract | Publisher Full Text | Free Full Text

98. Chryssanthou E, Broberger U, Petrini B: Malassezia pachydermatis fungaemia in a neonatal intensive care unit. Acta Paediatr. 2001; 90(3): 323-7. PubMed Abstract | Publisher Full Text

99. Chang HJ, Miller HL, Watkins N, et al.: An epidemic of Malassezia pachydermatis in an intensive care nursery associated with colonization of health care workers' pet dogs. $N$ Engl J Med. 1998; 338(11): 706-11. PubMed Abstract | Publisher Full Text

100. Surmont I, Gavilanes A, Vandepitte J, et al:: Malassezia furfur fungaemia in infants receiving intravenous lipid emulsions. A rarity or just underestimated? Eur J Pediatr. 1989; 148(5): 435-8. PubMed Abstract | Publisher Full Text

101. Tragiannidis A, Bisping G, Koehler G, et al:: Minireview: Malassezia infections in immunocompromised patients. Mycoses. 2010; 53(3): 187-95. PubMed Abstract | Publisher Full Text

102. F Kwon-Chung KJ: Taxonomy of fungi causing mucormycosis and entomophthoramycosis (zygomycosis) and nomenclature of the disease: molecular mycologic perspectives. Clin Infect Dis. 2012; 54(Suppl 1): S8-S15. PubMed Abstract | Publisher Full Text | Free Full Text | F1000 Recommendation

103. F Chakrabarti A, Chatterjee SS, Das A, et al:: Invasive zygomycosis in India: experience in a tertiary care hospital. Postgrad Med J. 2009; 85(1009): 573-81. PubMed Abstract | Publisher Full Text | F1000 Recommendation

104. Chander J, Singla N, Kaur M, et al:: Saksenaea erythrospora, an emerging mucoralean fungus causing severe necrotizing skin and soft tissue infections - a study from a tertiary care hospital in north India. Infect Dis (Lond). 2017; 49(3): 170-7.

PubMed Abstract | Publisher Full Text

105. F Gomes MZ, Lewis RE, Kontoyiannis DP: Mucormycosis caused by unusual 
mucormycetes, non-Rhizopus, -Mucor, and -Lichtheimia species. Clin Microbiol Rev. 2011; 24(2): 411-45.

PubMed Abstract | Publisher Full Text | Free Full Text | F1000 Recommendation

106. Ibrahim AS, Spellberg B, Walsh TJ, et al.: Pathogenesis of mucormycosis. Clin Infect Dis. 2012; 54(Suppl 1): S16-22.

PubMed Abstract | Publisher Full Text | Free Full Text

107. Petrikkos G, Skiada A, Lortholary O, et al.: Epidemiology and clinical manifestations of mucormycosis. Clin Infect Dis. 2012; 54(Suppl 1): S23-34. PubMed Abstract | Publisher Full Text

108. Skiada A, Pagano L, Groll A, et al:: Zygomycosis in Europe: analysis of 230 cases accrued by the registry of the European Confederation of Medical Mycology (ECMM) Working Group on Zygomycosis between 2005 and 2007. Clin Microbiol Infect. 2011; 17(12): 1859-67. PubMed Abstract | Publisher Full Text

109. Chamilos G, Marom EM, Lewis RE, et al:: Predictors of pulmonary zygomycosis versus invasive pulmonary aspergillosis in patients with cancer. Clin Infect Dis. 2005; 41(1): 60-6.

PubMed Abstract | Publisher Full Text

110. F Legouge $C$, Caillot $D$, Chrétien ML, et al.: The reversed halo sign: pathognomonic pattern of pulmonary mucormycosis in leukemic patients with neutropenia? Clin Infect Dis. 2014; 58(5): 672-8.

PubMed Abstract | Publisher Full Text | F1000 Recommendation

111. F Jung J, Kim MY, Lee HJ, et al:: Comparison of computed tomographic findings in pulmonary mucormycosis and invasive pulmonary aspergillosis. Clin Microbiol Infect. 2015; 21(7): 684.e11-8.

PubMed Abstract | Publisher Full Text | F1000 Recommendation

112. Georgiadou SP, Sipsas NV, Marom EM, et al.: The diagnostic value of halo and reversed halo signs for invasive mold infections in compromised hosts. Clin Infect Dis. 2011; 52(9): 1144-55.

PubMed Abstract | Publisher Full Text | Free Full Text

113. Haurany N, Kontoyiannis DP, Slavin MA, et al:: 4th Advances Against Aspergillosis. Rome, Italy: 2010. Interobserver reproducibility and concordance between culture and histopathology in invasive mold infections: a multicenter study. [abstract 78] Reference Source

114. Shah AA, Hazen KC: Diagnostic accuracy of histopathologic and cytopathologic examination of Aspergillus species. Am J Clin Pathol. 2013; 139(1): 55-61.

PubMed Abstract | Publisher Full Text

115. F Rickerts V, Mousset S, Lambrecht E, et al.: Comparison of histopathological analysis, culture, and polymerase chain reaction assays to detect invasive mold infections from biopsy specimens. Clin Infect Dis. 2007; 44(8): 1078-83. PubMed Abstract | Publisher Full Text | F1000 Recommendation

116. F Hammond SP, Bialek R, Milner DA, et al:: Molecular methods to improve diagnosis and identification of mucormycosis. J Clin Microbiol. 2011; 49(6): 2151-3.

PubMed Abstract | Publisher Full Text | Free Full Text | F1000 Recommendation

117. Dannaoui $\mathrm{E}$ : Molecular tools for identification of Zygomycetes and the diagnosis of zygomycosis. Clin Microbiol Infect. 2009; 15(Suppl 5): 66-70. PubMed Abstract | Publisher Full Text

118. Bialek R, Konrad F, Kern J, et al:: PCR based identification and discrimination of agents of mucormycosis and aspergillosis in paraffin wax embedded tissue. $J$ Clin Pathol. 2005; 58(11): 1180-4.

PubMed Abstract | Publisher Full Text | Free Full Text

119. Rickerts $V$, Just-Nübling $G$, Konrad F, et al.: Diagnosis of invasive aspergillosis and mucormycosis in immunocompromised patients by seminested PCR assay of tissue samples. Eur J Clin Microbiol Infect Dis. 2006; 25(1): 8-13. PubMed Abstract | Publisher Full Text

120. F Salehi E, Hedayati MT, Zoll J, et al:: Discrimination of Aspergillosis, Mucormycosis, Fusariosis, and Scedosporiosis in Formalin-Fixed ParaffinEmbedded Tissue Specimens by Use of Multiple Real-Time Quantitative PCR Assays. J Clin Microbiol. 2016; 54(11): 2798-803. PubMed Abstract | Publisher Full Text | Free Full Text | F1000 Recommendation

121. $F$ Dannaoui E, Schwarz $P$, Slany M, et al.: Molecular detection and identification of zygomycetes species from paraffin-embedded tissues in a murine model of disseminated zygomycosis: a collaborative European Society of Clinical Microbiology and Infectious Diseases (ESCMID) Fungal Infection Study Group (EFISG) evaluation. J Clin Microbiol. 2010; 48(6): 2043-6. PubMed Abstract | Publisher Full Text | Free Full Text | F1000 Recommendation

122. Hofman V, Dhouibi A, Butori $\mathrm{C}$, et al:: Usefulness of molecular biology performed with formaldehyde-fixed paraffin embedded tissue for the diagnosis of combined pulmonary invasive mucormycosis and aspergillosis in an immunocompromised patient. Diagn Pathol. 2010; 5: 1. PubMed Abstract | Publisher Full Text

123. Drogari-Apiranthitou M, Panayiotides I, Galani I, et al.: Diagnostic value of a semi-nested PCR for the diagnosis of mucormycosis and aspergillosis from paraffin-embedded tissue: A single center experience. Pathol Res Pract. 2016; 212(5): 393-7. PubMed Abstract | Publisher Full Text

124. F Millon L, Larosa F, Lepiller Q, et al:: Quantitative polymerase chain reaction detection of circulating DNA in serum for early diagnosis of mucormycosis in immunocompromised patients. Clin Infect Dis. 2013; 56(10): e95-101. PubMed Abstract | Publisher Full Text | F1000 Recommendation

125. Kasai M, Harrington SM, Francesconi A, et al.: Detection of a molecula biomarker for zygomycetes by quantitative PCR assays of plasma, bronchoalveolar lavage, and lung tissue in a rabbit model of experimental pulmonary zygomycosis. J Clin Microbiol. 2008; 46(11): 3690-702. PubMed Abstract | Publisher Full Text | Free Full Text

126. Walsh TJ, Gamaletsou MN, McGinnis MR, et al.: Early clinical and laboratory diagnosis of invasive pulmonary, extrapulmonary, and disseminated mucormycosis (zygomycosis). Clin Infect Dis. 2012; 54(Suppl 1): S55-60. PubMed Abstract | Publisher Full Text

127. Tissot $\mathrm{F}$, Agrawal $\mathrm{S}$, Pagano $\mathrm{L}$, et al.: ECIL-6 guidelines for the treatment of invasive candidiasis, aspergillosis and mucormycosis in leukemia and hematopoietic stem cell transplant patients. Haematologica. 2017; 102(3): 433-44.

PubMed Abstract | Publisher Full Text | Free Full Text

128. F Cornely OA, Arikan-Akdagli S, Dannaoui E, et al:: ESCMID and ECMM joint clinical guidelines for the diagnosis and management of mucormycosis 2013. Clin Microbiol Infect. 2014; 20(Suppl 3): 5-26.

PubMed Abstract | Publisher Full Text | F1000 Recommendation

129. Alastruey-Izquierdo A, Castelli MV, Cuesta I, et al.: Activity of posaconazole and other antifungal agents against Mucorales strains identified by sequencing of internal transcribed spacers. Antimicrob Agents Chemother. 2009; 53(4): 1686-9. PubMed Abstract | Publisher Full Text | Free Full Text

130. F Almyroudis NG, Sutton DA, Fothergill AW, et al.: In vitro susceptibilities of 217 clinical isolates of zygomycetes to conventional and new antifungal agents. Antimicrob Agents Chemother. 2007; 51(7): 2587-90. PubMed Abstract | Publisher Full Text | Free Full Text | F1000 Recommendation

131. F Lamoth F, Damonti L, Alexander BD: Role of Antifungal Susceptibility Testing in Non-Aspergillus Invasive Mold Infections. J Clin Microbiol. 2016; 54(6): 1638-40

PubMed Abstract | Publisher Full Text | Free Full Text | F1000 Recommendation

132. F Marty FM, Ostrosky-Zeichner L, Cornely OA, et al:: Isavuconazole treatment for mucormycosis: a single-arm open-label trial and case-control analysis. Lancet Infect Dis. 2016; 16(7): 828-37. PubMed Abstract | Publisher Full Text | F1000 Recommendation

133. $\mathrm{F}$ Kyvernitakis A, Torres HA, Jiang $\mathrm{Y}$, et al:: Initial use of combination treatment does not impact survival of 106 patients with haematologic malignancies and mucormycosis: a propensity score analysis. Clin Microbiol Infect. 2016; 22(9): 811.e1-811.e8. PubMed Abstract | Publisher Full Text | F1000 Recommendation

134. F Spellberg B, Ibrahim AS, Chin-Hong PV, et al:: The Deferasirox-AmBisome Therapy for Mucormycosis (DEFEAT Mucor) study: a randomized, doubleblinded, placebo-controlled trial. J Antimicrob Chemother. 2012; 67(3): 715-22. PubMed Abstract | Publisher Full Text | Free Full Text | F1000 Recommendation

135. F Ibrahim AS, Gebermariam T, Fu Y, et al.: The iron chelator deferasirox protects mice from mucormycosis through iron starvation. $J$ Clin Invest. 2007; 117(9): 2649-57.

PubMed Abstract | Publisher Full Text | Free Full Text | F1000 Recommendation

136. Jensen TSR, Arendrup MC, von Buchvald C, et al:: Successful Treatment of Rhino-Orbital-Cerebral Mucormycosis in a Child With Leukemia. J Pediatr Hematol Oncol. 2017; 39(4): e211-e215.

PubMed Abstract | Publisher Full Text

137. Gil-Lamaignere C, Simitsopoulou M, Roilides E, et al.: Interferon- gamma and granulocyte-macrophage colony-stimulating factor augment the activity of polymorphonuclear leukocytes against medically important zygomycetes. $J$ Infect Dis. 2005; 191(7): 1180-7.

PubMed Abstract | Publisher Full Text

138. Smith SN: An Overview of Ecological and Habitat Aspects in the Genus Fusarium with Special Emphasis on the Soil-Borne Pathogenic Forms. Plant Pathol Bull. 2007; 16: 97-120.

Reference Source

139. Salah H, Al-Hatmi AM, Theelen B, et al:: Phylogenetic diversity of human pathogenic Fusarium and emergence of uncommon virulent species. $J$ Infect. 2015; 71(6): 658-66. PubMed Abstract | Publisher Full Text

140. Al-Hatmi AM, Meis JF, de Hoog GS: Fusarium: Molecular Diversity and Intrinsic Drug Resistance. PLOS Pathog. 2016; 12(4): e1005464. PubMed Abstract | Publisher Full Text | Free Full Text

141. Nucci M, Anaissie E: Fusarium infections in immunocompromised patients. Clin Microbiol Rev. 2007; 20(4): 695-704. PubMed Abstract | Publisher Full Text | Free Full Text

142. Słowik M, Biernat MM, Urbaniak-Kujda D, et al.: Mycotic Infections of the Eye. Adv Clin Exp Med. 2015; 24(6): 1113-7. PubMed Abstract | Publisher Full Text

143. Dóczi I, Gyetvai T, Kredics L, et al.: Involvement of Fusarium spp. in fungal keratitis. Clin Microbiol Infect. 2004; 10(9): 773-6. PubMed Abstract | Publisher Full Text

144. Kalkanci A, Ozdek S: Ocular fungal infections. Curr Eye Res. 2011; 36(3): 179-89. PubMed Abstract | Publisher Full Text 
145. Oechsler RA, Yamanaka TM, Bispo PJ, et al.: Fusarium keratitis in Brazil: genotyping, in vitro susceptibilities, and clinical outcomes. Clin Ophthalmol. 2013; 7: 1693-701.

PubMed Abstract | Publisher Full Text | Free Full Text

146. Epstein $A B$ : In the aftermath of the Fusarium keratitis outbreak: What have we learned? Clin Ophthalmol. 2007; 1(4): 355-66. PubMed Abstract | Free Full Text

147. Tuft SJ, Tullo AB: Fungal keratitis in the United Kingdom 2003-2005. Eye (Lond). 2009; 23(6): 1308-13. PubMed Abstract | Publisher Full Text

148. F Ong HS, Fung SSM, Macleod D, et al: Altered Patterns of Fungal Keratitis at a London Ophthalmic Referral Hospital: An Eight-Year Retrospective Observational Study. Am J Ophthalmol. 2016; 168: 227-36. PubMed Abstract | Publisher Full Text | Free Full Text | F1000 Recommendation

149. Shukla PK, Kumar M, Keshava GB: Mycotic keratitis: an overview of diagnosis and therapy. Mycoses. 2008; 51(3): 183-99. PubMed Abstract | Publisher Full Text

150. Dignani MC, Anaissie E: Human fusariosis. Clin Microbiol Infect. 2004; 10(Suppl 1): $67-75$.

PubMed Abstract | Publisher Full Text

151. Tortorano AM, Richardson M, Roilides E, et al.: ESCMID and ECMM joint guidelines on diagnosis and management of hyalohyphomycosis: Fusarium spp., Scedosporium spp. and others. Clin Microbiol Infect. 2014; 20(Suppl 3): $27-46$.

PubMed Abstract | Publisher Full Text

152. Raad I, Tarrand J, Hanna H, et al.: Epidemiology, molecular mycology, and environmental sources of Fusarium infection in patients with cancer. Infect Control Hosp Epidemiol. 2002; 23(9): 532-7. PubMed Abstract | Publisher Full Text

153. Nucci M, Anaissie E: Cutaneous infection by Fusarium species in healthy and immunocompromised hosts: implications for diagnosis and management. Clin Infect Dis. 2002; 35(8): 909-20. PubMed Abstract | Publisher Full Text

154. Nucci F, Nouér SA, Capone D, et al.: Fusariosis. Semin Respir Crit Care Med. 2015; 36(5): 706-14.

PubMed Abstract | Publisher Full Text

155. F Kontoyiannis DP, Marr KA, Park BJ, et al.: Prospective surveillance for invasive fungal infections in hematopoietic stem cell transplant recipients, 2001-2006: overview of the Transplant-Associated Infection Surveillance Network (TRANSNET) Database. Clin Infect Dis. 2010; 50(8): 1091-100. PubMed Abstract | Publisher Full Text | F1000 Recommendation

156. Pagano L, Caira $M$, Nosari $A$, et al.: Fungal infections in recipients of hematopoietic stem cell transplants: results of the SEIFEM B-2004 studySorveglianza Epidemiologica Infezioni Fungine Nelle Emopatie Maligne. Clin Infect Dis. 2007; 45(9): 1161-70. PubMed Abstract | Publisher Full Text

157. Pagano L, Caira M, Candoni A, et al.: The epidemiology of fungal infections in patients with hematologic malignancies: the SEIFEM-2004 study. Haematologica. 2006; 91(8): 1068-75. PubMed Abstract

158. Nucci M, Garnica M, Gloria AB, et al: Invasive fungal diseases in haematopoietic cell transplant recipients and in patients with acute myeloid leukaemia or myelodysplasia in Brazil. Clin Microbiol Infect. 2013; 19(8): 745-51. PubMed Abstract | Publisher Full Text

159. Nucci M, Varon AG, Garnica M, et al.: Increased incidence of invasive fusariosis with cutaneous portal of entry, Brazil. Emerg Infect Dis. 2013; 19(10): 1567-72. PubMed Abstract | Publisher Full Text | Free Full Text

160. Varon AG, Nouer SA, Barreiros G, et al:: Superficial skin lesions positive for Fusarium are associated with subsequent development of invasive fusariosis. J Infect. 2014; 68(1): 85-9.

PubMed Abstract | Publisher Full Tex

161. F Anaissie EJ, Kuchar RT, Rex JH, et al: Fusariosis associated with pathogenic fusarium species colonization of a hospital water system: a new paradigm for the epidemiology of opportunistic mold infections. Clin Infect Dis. 2001; 33(11): 1871-8

PubMed Abstract | Publisher Full Text | F1000 Recommendation

162. O'Donnell K, Sutton DA, Rinaldi MG, et al.: Genetic diversity of human pathogenic members of the Fusarium oxysporum complex inferred from multilocus DNA sequence data and amplified fragment length polymorphism analyses: evidence for the recent dispersion of a geographically widespread clonal lineage and nosocomial origin. J Clin Microbiol. 2004; 42(11): 5109-20. PubMed Abstract | Publisher Full Text | Free Full Text

163. Tortorano AM, Prigitano A, Esposto MC, et al:: European Confederation of Medical Mycology (ECMM) epidemiological survey on invasive infections due to Fusarium species in Europe. Eur J Clin Microbiol Infect Dis. 2014; 33(9): 1623-30. PubMed Abstract | Publisher Full Tex

164. Al-Hatmi AM, Normand AC, van Diepeningen AD, et al.: Rapid identification of clinical members of Fusarium fujikuroi complex using MALDI-TOF MS. Future Microbiol. 2015; 10(12): 1939-52.

PubMed Abstract | Publisher Full Text

165. Bernal-Martínez L, Buitrago MJ, Castelli MV, et al:: Detection of invasive infection caused by Fusarium solani and non-Fusarium solani species using a duplex quantitative PCR-based assay in a murine model of fusariosis. Med Mycol. 2012; 50(3): 270-5.

PubMed Abstract | Publisher Full Text

166. Gu Z, Buelow DR, Petraitiene R, et al.: Quantitative multiplexed detection of common pulmonary fungal pathogens by labeled primer polymerase chain reaction. Arch Pathol Lab Med. 2014; 138(11): 1474-80.

PubMed Abstract | Publisher Full Text

167. $\mathrm{F}$ Espinel-Ingroff A, Colombo AL, Cordoba S, et al.: International Evaluation of MIC Distributions and Epidemiological Cutoff Value (ECV) Definitions for Fusarium Species Identified by Molecular Methods for the CLSI Broth Microdilution Method. Antimicrob Agents Chemother. 2016; 60(2): 1079-84. PubMed Abstract | Publisher Full Text | Free Full Text | F1000 Recommendation

168. Nucci M, Marr KA, Vehreschild MJ, et al.: Improvement in the outcome of invasive fusariosis in the last decade. Clin Microbiol Infect. 2014; 20(6): 580-5. PubMed Abstract | Publisher Full Text

169. Panackal AA, Marr KA: Scedosporium/Pseudallescheria infections. Semin Respir Crit Care Med. 2004; 25(2): 171-81. PubMed Abstract | Publisher Full Tex

170. Harun A, Perdomo H, Gilgado F, et al.: Genotyping of Scedosporium species: a review of molecular approaches. Med Mycol. 2009; 47(4): 406-14. PubMed Abstract | Publisher Full Tex

171. Cortez KJ, Roilides E, Quiroz-Telles F, et al:: Infections caused by Scedosporium spp. Clin Microbiol Rev. 2008; 21(1): 157-97. PubMed Abstract | Publisher Full Text | Free Full Text

172. Lackner M, de Hoog GS, Yang L, et al.: Proposed nomenclature for Pseudallescheria, Scedosporium and related genera. Fungal Divers. 2014; 67(1): $1-10$ Publisher Full Text

173. de Hoog GS, Haase G, Chaturvedi V, et al:: Taxonomy of medically important fungi in the molecular era. Lancet Infect Dis. 2013; 13(5): 385-6. PubMed Abstract | Publisher Full Text

174. Blyth CC, Middleton PG, Harun A, et al:: Clinical associations and prevalence of Scedosporium spp. in Australian cystic fibrosis patients: identification of novel risk factors? Med Mycol. 2010; 48(Suppl 1): S37-44. PubMed Abstract | Publisher Full Text

175. Zouhair R, Rougeron A, Razafimandimby B, et al.: Distribution of the different species of the Pseudallescheria boydii/Scedosporium apiospermum complex in French patients with cystic fibrosis. Med Mycol. 2013; 51(6): 603-13. PubMed Abstract | Publisher Full Text

176. Kantarcioglu AS, Guarro J, de Hoog GS: Central nervous system infections by members of the Pseudallescheria boydii species complex in healthy and immunocompromised hosts: epidemiology, clinical characteristics and outcome. Mycoses. 2008; 51(4): 275-90. PubMed Abstract | Publisher Full Text

177. Pagano L, Caira M, Falcucci $P$, et al.: Fungal CNS infections in patients with hematologic malignancy. Expert Rev Anti Infect Ther. 2005; 3(5): 775-85. PubMed Abstract | Publisher Full Text

178. Katragkou A, Dotis J, Kotsiou M, et al:: Scedosporium apiospermum infection after near-drowning. Mycoses. 2007; 50(5): 412-21. PubMed Abstract | Publisher Full Text

179. Rüchel R, Wilichowski E: Cerebral Pseudallescheria mycosis after neardrowning. Mycoses. 1995; 38(11-12): 473-5. PubMed Abstract | Publisher Full Text

180. Leechawengwongs M, Milindankura S, Liengudom A, et al.: Multiple Scedosporium apiospermum brain abscesses after near-drowning successfully treated with surgery and long-term voriconazole: a case report. Mycoses. 2007; 50(6): 512-6. PubMed Abstract | Publisher Full Text

181. Mesfin FB, Tobin E, Adamo MA, et al.: Fungal vertebral osteomyelitis due to Scedosporium apiospermum after near-drowning. J Neurosurg Spine. 2008; 9(1): 58-61. PubMed Abstract | Publisher Full Text

182. Nakamura $\mathrm{Y}$, Utsumi $\mathrm{Y}$, Suzuki $\mathrm{N}$, et al.: Multiple Scedosporium apiospermum ascesses in a woman survivor of a tsunami in northeastern Japan: a case report. J Med Case Rep. 2011; 5: 526. PubMed Abstract | Publisher Full Text | Free Full Text

183. Shimizu J, Yoshimoto M, Takebayashi T, et al.: Atypical fungal vertebral osteomyelitis in a tsunami survivor of the Great East Japan Earthquake. Spine (Phila Pa 1976). 2014; 39(12): E739-42. PubMed Abstract | Publisher Full Text

184. $\mathrm{F} \mathrm{He} \mathrm{XH}$, Wu JY, Wu CJ, et al: Scedosporium Apiospermum Infection after Near-drowning. Chin Med J (Engl). 2015; 128(15): 2119-23. PubMled Abstract | Publisher Full Text | Free Full Text | F1000 Recommendation

185. F Chen TC, Ho MW, Chien WC, et al.: Disseminated Scedosporium apiospermum infection in a near-drowning patient. J Formos Med Assoc. 2016 115(3): 213-4

PubMed Abstract | Publisher Full Text | F1000 Recommendation

186. F Kim SH, Ha YE, Youn JC, et al:: Fatal scedosporiosis in multiple solid organ allografts transmitted from a nearly-drowned donor. Am J Transplant. 2015; 15(3): 833-40.

PubMed Abstract | Publisher Full Text | F1000 Recommendation 
187. F Leek R, Aldag E, Nadeem I, et al:: Scedosporiosis in a Combined Kidney and Liver Transplant Recipient: A Case Report of Possible Transmission from a Near-Drowning Donor. Case Rep Transplant. 2016; 2016: 1879529. PubMed Abstract | Publisher Full Text | Free Full Text | F1000 Recommendation

188. Rodriguez-Tudela JL, Berenguer J, Guarro J, et al:: Epidemiology and outcom of Scedosporium prolificans infection, a review of 162 cases. Med Mycol. 2009; 47(4): 359-70.

PubMed Abstract | Publisher Full Text

189. Hennebert GL, Desai BG: Lomentospora prolificans, a new hyphomycete from greenhouse soil. Mycotaxon. 1974; 1(1): 45-50.

190. Lackner M, de Hoog GS: Scedosporium spp.: emerging agents of systemic disease. J Invasive Fungal Infect. 2011; 5(2): 43-7. Reference Source

191. F Meletiadis J, Meis JF, Mouton JW, et al.: In vitro activities of new and conventional antifungal agents against clinical Scedosporium isolates. Antimicrob Agents Chemother. 2002; 46(1): 62-8.

PubMed Abstract | Publisher Full Text | Free Full Text | F1000 Recommendation

192. Schemuth H, Dittmer S, Lackner M, et al.: In vitro activity of colistin as single agent and in combination with antifungals against filamentous fungi occurring in patients with cystic fibrosis. Mycoses. 2013; 56(3): 297-303. PubMed Abstract | Publisher Full Text

193. Howden BP, Slavin MA, Schwarer AP, et al:: Successful control of disseminated Scedosporium prolificans infection with a combination of voriconazole and terbinafine. Eur J Clin Microbiol Infect Dis. 2003; 22(2): 111-3. PubMed Abstract

194. Bhat SV, Paterson DL, Rinaldi MG, et al.: Scedosporium prolificans brain abscess in a patient with chronic granulomatous disease: successful combination therapy with voriconazole and terbinafine. Scand J Infect Dis. 2007; 39(1): 87-90. PubMed Abstract | Publisher Full Text

195. Tong SY, Peleg AY, Yoong J, et al.: Breakthrough Scedosporium prolificans infection while receiving voriconazole prophylaxis in an allogeneic stem cell transplant recipient. Transpl Infect Dis. 2007; 9(3): 241-3. PubMed Abstract | Publisher Full Text

196. Gosbell IB, Toumasatos V, Yong J, et al.: Cure of orthopaedic infection with Scedosporium prolificans, using voriconazole plus terbinafine, without the need for radical surgery. Mycoses. 2003; 46(5-6): 233-6. PubMed Abstract | Publisher Full Text

197. Li JY, Yong TY, Grove DI, et al.: Successful control of Scedosporium prolificans septic arthritis and probable osteomyelitis without radical surgery in a longterm renal transplant recipient. Transpl Infect Dis. 2008; 10(1): 63-5. PubMed Abstract | Publisher Full Text

198. Borman AM, Palmer MD, Delhaes L, et al:: Lack of standardization in the procedures for mycological examination of sputum samples from CF patients: a possible cause for variations in the prevalence of filamentous fungi. Med Mycol. 2010; 48 Suppl 1: S88-97. PubMed Abstract | Publisher Full Text

199. Schwartz S, Reisman A, Troke PF: The efficacy of voriconazole in the treatmen of 192 fungal central nervous system infections: a retrospective analysis. Infection. 2011; 39(3): 201-10. PubMed Abstract | Publisher Full Text

200. Verweij PE, Cox NJ, Meis JF: Oral terbinafine for treatment of pulmonary Pseudallescheria boydii infection refractory to itraconazole therapy. Eur J Clin Microbiol Infect Dis. 1997; 16(1): 26-8. PubMed Abstract | Publisher Full Text

201. Husain S, Muñoz P, Forrest G, et al.: Infections due to Scedosporium apiospermum and Scedosporium prolificans in transplant recipients: clinical characteristics and impact of antifungal agent therapy on outcome. Clin Infect Dis. 2005; 40(1): 89-99. PubMed Abstract | Publisher Full Tex

202. Rogasi PG, Zanazzi M, Nocentini J, et al.: Disseminated Scedosporium apiospermum infection in renal transplant recipient: long-term successfu treatment with voriconazole: a case report. Transplant Proc. 2007; 39(6): 2033-5 PubMed Abstract | Publisher Full Text

203. Musk M, Chambers D, Chin W, et al:: Successful treatment of disseminated scedosporium infection in 2 lung transplant recipients: review of the literature and recommendations for management. $J$ Heart Lung Transplant. 2006; 25(10): 1268-72. PubMed Abstract | Publisher Full Text

204. Nomdedéu J, Brunet S, Martino R, et al.: Successful treatment of pneumonia due to Scedosporium apiospermum with itraconazole: case report. Clin Infect Dis. 1993; 16(5): 731-3.

PubMed Abstract | Publisher Full Tex

205. Berenguer J, Rodríguez-Tudela JL, Richard C, et al.: Deep infections caused by Scedosporium prolificans. A report on 16 cases in Spain and a review of the literature. Scedosporium Prolificans Spanish Study Group. Medicine (Baltimore). 1997; 76(4): 256-65. PubMed Abstract

206. Bouza E, Muñoz P, Vega L, et al.: Clinical resolution of Scedosporium prolificans fungemia associated with reversal of neutropenia following administration of granulocyte colony-stimulating factor. Clin Infect Dis. 1996; 23(1): 192-3.

PubMed Abstract | Publisher Full Text
207. Luangsa-Ard J, Houbraken J, van Doorn T, et al:: Purpureocillium, a new genus for the medically important Paecilomyces lilacinus. FEMS Microbiol Lett. 2011 321(2): 141-9.

PubMed Abstract | Publisher Full Text

208. F Chamilos G, Kontoyiannis DP: Voriconazole-resistant disseminated Paecilomyces variotii infection in a neutropenic patient with leukaemia on voriconazole prophylaxis. J Infect. 2005; 51(4): e225-8.

PubMed Abstract | Publisher Full Text | F1000 Recommendation

209. Orth B, Frei R, Itin $\mathrm{PH}$, et al:: Outbreak of invasive mycoses caused by Paecilomyces lilacinus from a contaminated skin lotion. Ann Intern Med. 1996; 125(10): 799-806.

PubMed Abstract | Publisher Full Text

210. F Houbraken J, Verweij PE, Rijs AJ, et al.: Identification of Paecilomyces variotii in clinical samples and settings. J Clin Microbiol. 2010; 48(8): 2754-61. PubMed Abstract | Publisher Full Text | Free Full Text | F1000 Recommendation

211. Salle V, Lecuyer E, Chouaki $\mathrm{T}$, et al:: Paecilomyces variotii fungemia in a patient with multiple myeloma: case report and literature review. J Infect. 2005; 51(3): e93-5. PubMed Abstract | Publisher Full Text

212. Wang SM, Shieh CC, Liu CC: Successful treatment of Paecilomyces variotii splenic abscesses: a rare complication in a previously unrecognized chronic granulomatous disease child. Diagn Microbiol Infect Dis. 2005; 53(2): 149-52. PubMed Abstract | Publisher Full Text

213. Shing MM, Ip M, Li CK, et al.: Paecilomyces varioti fungemia in a bone marrow transplant patient. Bone Marrow Transplant. 1996; 17(2): 281-3. PubMed Abstract

214. Pastor FJ, Guarro J: Clinical manifestations, treatment and outcome of Paecilomyces lilacinus infections. Clin Microbiol Infect. 2006; 12(10): 948-60. PubMed Abstract | Publisher Full Text

215. Barker AP, Horan JL, Slechta ES, et al:: Complexities associated with the molecular and proteomic identification of Paecilomyces species in the clinical mycology laboratory. Med Mycol. 2014; 52(5): 537-45.

PubMed Abstract | Publisher Full Tex

216. F Revankar SG, Sutton DA: Melanized fungi in human disease. Clin Microbio Rev. 2010; 23(4): 884-928. PubMed Abstract | Publisher Full Text | Free Full Text | F1000 Recommendation

217. Jacobson ES: Pathogenic roles for fungal melanins. Clin Microbiol Rev. 2000; 13(4): 708-17. PubMed Abstract | Publisher Full Text | Free Full Text

218. Hamilton AJ, Gomez BL: Melanins in fungal pathogens. J Med Microbiol. 2002; 51(3): 189-91. PubMed Abstract | Publisher Full Text

219. Wong EH, Revankar SG: Dematiaceous Molds. Infect Dis Clin North Am. 2016; 30(1): 165-78. PubMed Abstract | Publisher Full Text

220. Chowdhary A, Meis JF, Guarro J, et al.: ESCMID and ECMM joint clinical guidelines for the diagnosis and management of systemic phaeohyphomycosis: diseases caused by black fungi. Clin Microbiol Infect. 2014; 20 Suppl 3: 47-75. PubMed Abstract | Publisher Full Text

221. Abbas KM, Dorratoltaj N, O'Dell ML, et al.: Clinical Response, Outbreak Investigation, and Epidemiology of the Fungal Meningitis Epidemic in the United States: Systematic Review. Disaster Med Public Health Prep. 2016; 10(1): $145-51$. PubMed Abstract | Publisher Full Text | Free Full Text

222. $\mathrm{F}$ Kenyon $\mathrm{C}$, Bonorchis $\mathrm{K}$, Corcoran $\mathrm{C}$, et al:: A dimorphic fungus causing disseminated infection in South Africa. N Engl J Med. 2013; 369(15): 1416-24. PubMed Abstract | Publisher Full Text | F1000 Recommendation

223. F Schwartz IS, Kenyon C, Feng P, et al.: $\mathbf{5 0}$ Years of Emmonsia Disease in Humans: The Dramatic Emergence of a Cluster of Novel Fungal Pathogens. PLoS Pathog. 2015; 11(11): e1005198.

PubMed Abstract | Publisher Full Text | Free Full Text | F1000 Recommendation

224. $\mathrm{F}$ Yang $\mathrm{Y}, \mathrm{Ye} \mathrm{Q}$, Li K, et al.: Genomics and Comparative Genomic Analyses Provide Insight into the Taxonomy and Pathogenic Potential of Nove Emmonsia Pathogens. Front Cell Infect Microbiol. 2017; 7: 105. PubMed Abstract | Publisher Full Text | Free Full Text | F1000 Recommendation

225. Gori $\mathrm{S}$, Drouhet $\mathrm{E}$, Guého $\mathrm{E}$, et al:: Cutaneous disseminated mycosis in a patient with AIDS due to a new dimorphic fungus. J Mycol Med. 1998; 8: 57-63. Reference Source

226. Drouhet E, Guého E, Gori S, et al.: Mycological, ultrastructural and experimental aspects of a new dimorphic fungus Emmonsia pasteuriana sp. nov. isolated from a cutaneous disseminated mycosis in AIDS. J Mycol Med. 1998; 8: 64-77. Reference Source

227. Pelegrín I, Ayats J, Xiol X, et al:: Disseminated adiaspiromycosis: case report of a liver transplant patient with human immunodeficiency infection, and literature review. Transpl Infect Dis. 2011; 13(5): 507-14. PubMed Abstract | Publisher Full Text

228. Dukik K, Muñoz JF, Jiang $Y$, et al.: Novel taxa of thermally dimorphic systemic pathogens in the Ajellomycetaceae (Onygenales). Mycoses. 2017; 60(5): 296-309. PubMed Abstract | Publisher Full Text

229. Schwartz IS, Govender NP, Corcoran C, et al.: Clinical Characteristics, 
Diagnosis, Management, and Outcomes of Disseminated Emmonsiosis: A Retrospective Case Series. Clin Infect Dis. 2015; 61(6): 1004-12. PubMed Abstract | Publisher Full Text

230. Samson RA, Yilmaz N, Houbraken J, et al.: Phylogeny and nomenclature of the genus Talaromyces and taxa accommodated in Penicillium subgenus Biverticillium. Stud Mycol. 2011; 70(1): 159-83. PubMed Abstract | Publisher Full Text | Free Full Text

231. Vanittanakom N, Cooper CR Jr, Fisher MC, et al:: Penicillium marneffei infection and recent advances in the epidemiology and molecular biology aspects. Clin Microbiol Rev. 2006; 19(1): 95-110. PubMed Abstract | Publisher Full Text | Free Full Text

232. Supparatpinyo K, Khamwan C, Baosoung V, et al.: Disseminated Penicillium marneffei infection in southeast Asia. Lancet. 1994; 344(8915): 110-3. PubMed Abstract | Publisher Full Text

233. Ustianowski AP, Sieu TP, Day JN: Penicillium marneffei infection in HIV. Curr Opin Infect Dis. 2008; 21(1): 31-6.

PubMed Abstract | Publisher Full Text

234. F Chan JF, Lau SK, Yuen KY, et al.: Talaromyces (Penicillium) marneffei infection in non-HIV-infected patients. Emerg Microbes Infect. 2016; 5(3): e19. PubMed Abstract | Publisher Full Text | Free Full Text | F1000 Recommendation

235. Chan JF, Chan TS, Gill H, et al: Disseminated Infections with Talaromyces marneffei in Non-AIDS Patients Given Monoclonal Antibodies against CD20 and Kinase Inhibitors. Emerg Infect Dis. 2015; 21(7): 1101-6. PubMed Abstract | Publisher Full Text | Free Full Text

236. Tse E, Leung RY, Kwong Y: Invasive fungal infections after obinutuzumab monotherapy for refractory chronic lymphocytic leukemia. Ann Hematol. 2015; 94(1): 165-7. PubMed Abstract | Publisher Full Text

237. Tang BS, Chan JF, Chen M, et al.: Disseminated penicilliosis, recurrent bacteremic nontyphoidal salmonellosis, and burkholderiosis associated with acquired immunodeficiency due to autoantibody against gamma interferon. Clin Vaccine Immunol. 2010; 17(7): 1132-8.

PubMed Abstract | Publisher Full Text | Free Full Text
238. F Hermans F, Ombelet S, Degezelle K, et al:: First-in-man observation of Talaromyces marneffei-transmission by organ transplantation. Mycoses. 2017; 60(3): 213-7.

PubMed Abstract | Publisher Full Text | F1000 Recommendation

239. Mohsin J, Khalili SA, van den Ende AHGG, et al.: Imported Talaromycosis in Oman in Advanced HIV: A Diagnostic Challenge Outside the Endemic Areas. Mycopathologia. 2017; 182(7-8): 739-45. PubMed Abstract | Publisher Full Text | Free Full Text

240. Hu Y, Zhang J, Li X, et al:: Penicillium marneffei infection: an emerging disease in mainland China. Mycopathologia. 2013; 175(1-2): 57-67. PubMed Abstract | Publisher Full Text

241. Supparatpinyo K, Sirisanthana T: Disseminated Penicillium marneffei infection diagnosed on examination of a peripheral blood smear of a patient with human immunodeficiency virus infection. Clin Infect Dis. 1994; 18(2): 246-7. PubMed Abstract | Publisher Full Text

242. F Hien HT, Thanh TT, Thu NT, et al:: Development and evaluation of a realtime polymerase chain reaction assay for the rapid detection of Talaromyces marneffei MP1 gene in human plasma. Mycoses. 2016; 59(12): 773-780. PubMed Abstract | Publisher Full Text | Free Full Text | F1000 Recommendation

243. F Lau SK, Lam CS, Ngan AH, et al.: Matrix-assisted laser desorption ionization time-of-flight mass spectrometry for rapid identification of mold and yeast cultures of Penicillium marneffei. BMC Microbiol. 2016; 16: 36. PubMed Abstract | Publisher Full Text | Free Full Text | F1000 Recommendation

244. Sirisanthana T, Supparatpinyo K, Perriens J, et al.: Amphotericin B and itraconazole for treatment of disseminated Penicillium marneffei infection in human immunodeficiency virus-infected patients. Clin Infect Dis. 1998; 26(5): 1107-10.

PubMed Abstract | Publisher Full Text

245. Supparatpinyo K, Schlamm HT: Voriconazole as therapy for systemic Penicillium marneffei infections in AIDS patients. Am J Trop Med Hyg. 2007; 77(2): $350-3$.

PubMed Abstract 


\section{Open Peer Review}

\section{Current Peer Review Status:}

\section{Editorial Note on the Review Process}

Faculty Reviews are review articles written by the prestigious Members of Faculty Opinions. The articles are commissioned and peer reviewed before publication to ensure that the final, published version is comprehensive and accessible. The reviewers who approved the final version are listed with their names and affiliations.

\section{The reviewers who approved this article are:}

\section{Version 1}

\section{Flavio Queiroz-Telles}

Division of Infectious Diseases, Federal University of Paraná, Curitiba, Brazil

Competing Interests: No competing interests were disclosed.

\section{Tania C Sorrell}

${ }^{1}$ Centre for Infectious Diseases and Microbiology, University of Sydney at Westmead Hospital, Westmead, New South Wales, Australia

2 Marie Bashir Institute for Infectious Diseases and Biosecurity, University of Sydney, Westmead, New South Wales, Australia

Competing Interests: No competing interests were disclosed.

\section{Jean-Phillipe Bouchara}

1 Groupe d'Etude des Interactions Hôte-Pathogène, Université d'Angers, Angers, EA 3142, France

2 Laboratoire de Parasitologie-Mycologie, Centre Hospitalier Universitaire d"Angers, Angers, France Competing Interests: No competing interests were disclosed.

\section{Jacques Meis}

Department of Medical Microbiology and Infectious Diseases, Canisius-Wilhelmina Hospital(CWZ), and Centre of Expertise in Mycology Radboudumc/CWZ, Nijmegen, The Netherlands

Competing Interests: No competing interests were disclosed. 
The benefits of publishing with F1000Research:

- Your article is published within days, with no editorial bias

- You can publish traditional articles, null/negative results, case reports, data notes and more

- The peer review process is transparent and collaborative

- Your article is indexed in PubMed after passing peer review

- Dedicated customer support at every stage

For pre-submission enquiries, contact research@f1000.com 